Defraeye T., Verboven P., Ho Q.T., Nicolai B., Convective heat and mass exchange predictions at leaf surfaces: applications, methods and perspectives, Computers and Electronics in Agriculture 96, 180-201. http://dx.doi.org/10.1016/j.compag.2013.05.008

\title{
Convective heat and mass exchange predictions at leaf surfaces: applications, methods and perspectives
}

\author{
Thijs Defraeye ${ }^{\text {a, * }}$, Pieter Verboven ${ }^{\text {a }}$, Quang Tri Ho ${ }^{\text {a }}$, Bart Nicolai ${ }^{\text {a,b }}$ \\ ${ }^{a}$ MeBioS, Department of Biosystems, University of Leuven, Willem de Croylaan 42, 3001 Heverlee, Belgium \\ ${ }^{b}$ VCBT, Flanders Centre of Postharvest Technology, Willem de Croylaan 42, 3001 Heverlee, Belgium
}

\begin{abstract}
$\underline{\text { Abstract }}$
Convective heat and mass exchange of leaves with the environment is relevant for a better understanding of plant physiological processes in response to environmental factors for a wide range of applications. Methods for quantifying these exchanges have been subject of active research, as they allow to explain the functions of leaves, their effects on gas and water transport in plants, and the heat and mass exchange of plant canopies with the environment. Furthermore, they provide input on these exchange rates to simulation models of pre- and postharvest operations and of leaf/plant/tree/canopy-environment systems. An overview is given on the different methods to obtain convective transfer predictions, namely analytical, experimental (i.e., by laboratory or field tests) and numerical methods, and their restrictions and current knowledge gaps are identified. Analytical methods for flat plates are the most simplified approach but lack physical similarity with real leaves. The majority of the methods used are however sensor-based, using real, artificial but also virtual leaf sensors. For experimental research in the field or in the laboratory (e.g., wind tunnel), special attention is given here to the sensors used, namely real and artificial leaves. Numerical methods are based on computational fluid dynamics (CFD) simulations to predict air-side convective transfer on virtual leaves, but have not been readily applied at leaf and sub-leaf level, despite their large potential here. Instead of commonly-used convective transfer coefficients, CFD allows direct, case-specific predictions of convective transfer, at different levels of complexity and at a very high spatial and temporal resolution. A particular difficulty in all methods is to account for stomata, which result in very heterogeneous heat and mass boundary conditions over the leaf surface at microscale level, and also for microscale surface roughness (e.g., trichomes). Future perspectives are mainly oriented towards CFD, but the challenge will be to model convective transfer at multiple scales and to couple them using a multiscale approach.
\end{abstract}

\footnotetext{
* Corresponding author. Tel.: +32 (0)16321618; fax: +32 (0)16322966.

E-mail address: thijs.defraeye@ biw.kuleuven.be
} 
Defraeye T., Verboven P., Ho Q.T., Nicolai B., Convective heat and mass exchange predictions at leaf surfaces: applications, methods and perspectives, Computers and Electronics in Agriculture 96, 180-201. http://dx.doi.org/10.1016/j.compag.2013.05.008

\section{$\underline{\text { Keywords }}$}

Convective transfer coefficient; Artificial leaf; Plant; Transpiration; Stomata; Review 
Defraeye T., Verboven P., Ho Q.T., Nicolai B., Convective heat and mass exchange predictions at leaf surfaces: applications, methods and perspectives, Computers and Electronics in Agriculture 96, 180-201. http://dx.doi.org/10.1016/j.compag.2013.05.008

\section{Introduction}

Plants interact with their environment by exchanging heat and mass in several ways. The most important exchange processes are photosynthesis $\left(\mathrm{CO}_{2}\right.$ fixation and $\mathrm{O}_{2}$ release) and the related respiration and plant transpiration $\left(\mathrm{H}_{2} \mathrm{O}\right.$ release), which all occur in leaves. As the majority of plant water loss occurs by transpiration, leaves also play a dominant role in the plant hydrological cycle. Furthermore, leaves have a distinct impact on the air flow through the plant canopy and on solar radiation absorption and long-wave radiation since they comprise the majority of the surface area of all plant organs. Leaves are actually considered the most important heat, mass and momentum sources or sinks in the plant canopy (Schuepp, 1993) by which they have a clear impact on the local plant/canopy microclimate. An important component in the heat and mass balances at the leaf surface is the convective heat and mass exchange of leaves with the environment, i.e., via the boundary layer on the leaf surface. Knowledge of these convective leaf-air exchange processes is therefore, amongst others, required for the analysis of multiple physiological processes in plants and leaves and their interaction with the environment, but also for related applications in biosystems engineering, as indicated in the following paragraphs.

Plant growth is strongly dependent on convective exchange processes at leaf surfaces (Chen, 2003; Shibuya et al., 2006), particularly due to their impact on leaf temperature, which influences almost all leaf (and plant) metabolic processes, but also on the temperature of branches and buds (Michaletz and Johnson, 2006). An increased leaf temperature, e.g., due to solar absorption, leads to higher photosynthesis (and $\mathrm{CO}_{2}$ conversion) rates but, conversely, too high temperatures can be lethal. Leaf temperatures are reduced by convective cooling and evaporative cooling. The latter is a consequence of transpiration. It can also result from evaporation of water droplets on the surface (rain, dew). Evaporative cooling is one of the main temperature reducing mechanisms of leaves, indicating the coupling between convective heat and mass exchange. Leaf temperature also affects leaf morphology (Reich et al., 2004; Maricle et al., 2007; Mishio et al., 2007; Picotte et al., 2007; Shahba and Bauerle, 2009): e.g., sunny leaves are usually smaller, thicker and more deeply lobed or serrated than shaded leaves, and have a higher stomatal density (Schuepp, 1993) to enhance convective cooling and transpiration. Apart from leaf temperature, convection also influences plant growth by increasing gas exchange within plant canopies, thus photosynthesis (Shibuya et al., 2006), and by inducing transport of water, minerals and nutrients within plants, via transpiration. The majority ( $\sim 80 \%)$ of the water used by plants, is however not directly required for physiological growth (e.g., Cannon et al., 1979), but is merely transported from the soil through the plant and transpired into the air.

Hence, plant water availability and water stress are also closely related to convective exchange processes (Monteith, 1995; Smith et al., 1997a; Smith and Jarvis, 1998; Bauerle and Bowden, 2011). Water and its availability is the single most important 
Defraeye T., Verboven P., Ho Q.T., Nicolai B., Convective heat and mass exchange predictions at leaf surfaces: applications, methods and perspectives, Computers and Electronics in Agriculture 96, 180-201.

http://dx.doi.org/10.1016/j.compag.2013.05.008

problem in global agricultural production (Rijsberman, 2006) as it is one of the main abiotic factors limiting crop production: losses in crop yield due to water stress exceed losses due to all other biotic and environmental factors combined (Lambers et al., 2008). Under water stress, plants react in order to reduce the convective water removal from the leaf by transpiration: stomata close, leaf orientation can change (Vogel, 2009) and some leaves curl (Renard and Demessemacker, 1983) or rearrange (e.g., paraheliotropic leaf movement; Ludlow and Björkman, 1984).

Convective exchange processes also influence the local leaf microclimate and biochemical processes in the boundary layer at the leaf surface. Hereto, water (droplet) evaporation from leaf surfaces is especially relevant as water availability (wetness) at the surface has an impact on dry deposition of atmospheric pollutants (Schuepp, 1982; Unsworth and Wilshaw, 1989), neutralisation of acid rain (Musselman, 1988) and development of pathogens (Zakharenkova et al., 2012). Pesticide efficiency is also dependent on the pesticide droplet evaporation rate, thus the droplet lifetime (Boehncke et al., 1990; Yu et al., 2009a, 2009b; Glass et al., 2010; Xu et al., 2010): rapid evaporation can result in insufficient droplet spreading, reduced absorption of active chemical components and formation of crystals, whereas slow evaporation may induce germination of pathogens. Similarly, water droplet formation (i.e., dew) or ice formation (i.e., frost) depend on the convective exchange (Jordan and Smith, 1994). Furthermore, the boundary-layer microclimate serves as a microhabitat of organisms, such as insects (e.g., whitefly) or bacterial and fungal pathogens (Boulard et al., 2002; Vidal et al., 2003), but also bioinsecticides (Fargues et al., 2005; Roy et al., 2008). Via the boundary layer, leaves of several species also emit biogenic volatile organic compounds (e.g., hydrocarbons) into the atmosphere as a defence mechanism against herbivores, to supress plant pathogens or to induce plantto-plant signalling (Holopainen, 2004). These compounds however affect atmospheric chemistry (Lerdau et al., 1997; ozone production, methane oxidation and the global carbon monoxide budget).

Apart from these physiological plant processes, convective exchange of leaves with the environment is also subject of active research in several pre- and postharvest applications: (1) Optimisation of greenhouse ventilation strategies and ventilation system design (Iqbal and Stoffers, 1975; Mistriotis et al., 1997; Katsoulas et al., 2001; Kittas et al., 2001; Boulard and Wang, 2002; Boulard et al., 2002, 2004; Katsoulas et al., 2007; Impron et al., 2008; Franco et al., 2011; Vermeulen et al., 2012), with respect to greenhouse climate, (evapo)transpiration control, water stress and water use efficiency; (2) Convective and vacuum cooling of leafy vegetables (e.g., lettuce), namely to minimise cooling times and to optimise cooler performance (Sun and Zheng, 2006); (3) Convective drying of leaves (parsley, nettle, mint, etc.) to optimise processing efficiency, in terms of energy usage and drying time, without compromising product quality (Kaya and Aydin, 2009; Köse and Erentürk, 2010); (4) Longterm storage of leafy vegetables, as storage time, shelf life, quality (e.g., firmness), weight loss, mould growth risk and 
Defraeye T., Verboven P., Ho Q.T., Nicolai B., Convective heat and mass exchange predictions at leaf surfaces: applications, methods and perspectives, Computers and Electronics in Agriculture 96, 180-201. http://dx.doi.org/10.1016/j.compag.2013.05.008

postharvest treatment are strongly related to transpiration, respiration and heat transfer (Hodges and Toivonen, 2008); (5) Optimisation of evaporative cooling potential by mist chilling (Allais et al., 2006) or hydro-air cooling (Abdul Majeed, 1981); (6) Protection of crops against freezing (Kumar and Barthakur, 1971; Saldin and Barthakur, 1971; Leuning and Cremer, 1988).

Finally, convective transfer predictions are indispensable for numerical modelling of leaf/plant/tree/canopy-environment systems (Friend, 1995; Monteith, 1995; Smith et al., 1997a; Dauzat et al., 2001; Tanaka, 2002; Tanaka et al., 2002; Hiraoka, 2005; Kosugi et al., 2006; Maricle et al., 2007). Such models are widely used in plant microclimatology or urban and boundary-layer meteorology as an alternative to experimental laboratory or field studies (e.g., Gromke and Ruck, 2007; Gromke, 2012). In these models, which predict the tree or canopy heat and/or mass balance, convective exchange processes are implemented using submodels, which require realistic input. Also, convective transfer estimates are critical for modelling of forest fire propagation (Silvani and Morandini, 2009; Lamorlette and Collin, 2012).

Having indicated the importance of convective heat and mass exchange of leaves with the environment, this study will give an overview on how such convective scalar transfer predictions can be obtained analytically, experimentally (i.e., by laboratory or field tests) or numerically. Such predictions are essential for a better understanding of the leaf-environment interaction, as well as for optimizing plant growth and designing postharvest systems, and apply predominantly sensor-based methods, using real, artificial but also virtual leaf sensors. A lot of valuable research was already performed in the past but still some restrictions are present with the current techniques, leading to knowledge gaps with respect to the resulting predictions. Previous reviews (Raschke, 1960; Schuepp, 1993; Vogel, 2009) dealt with the impact of convective transfer on several physiological processes (e.g., leaf morphology, stomatal opening, sun-shade dimorphism, phenotype plasticity) or with the different factors influencing convective exchange (e.g., leaf shape, microscale morphology, turbulence), but did not focus in particular on how these convective transfer predictions are obtained. As in most previous studies, the present study will focus on water $\left(\mathrm{H}_{2} \mathrm{O}\right)$ as the mass transfer component, but generalisation to other substances (e.g., $\mathrm{CO}_{2}$ ) is often straightforward. First, some basic characteristics of convective transfer processes for leaves are briefly discussed as these are essential to evaluate the performance of the current methods. Afterwards, an overview of existing analytical, experimental and numerical methods to predict convective transfer is given and their limitations are discussed. Based on these findings, the current knowledge gaps with respect to convective transfer predictions are discussed and future perspectives are given.

\section{Convective scalar exchange at leaf surfaces}


Defraeye T., Verboven P., Ho Q.T., Nicolai B., Convective heat and mass exchange predictions at leaf surfaces: applications, methods and perspectives, Computers and Electronics in Agriculture 96, 180-201.

http://dx.doi.org/10.1016/j.compag.2013.05.008

\subsection{Convective transfer coefficients}

The boundary layer on a leaf surface is a region with strong gradients in air velocity, temperature and gas concentrations (such as $\mathrm{H}_{2} \mathrm{O}, \mathrm{CO}_{2}$ and $\mathrm{O}_{2}$ ), which decrease further away from the surface. Its thickness varies from below $1 \mathrm{~mm}$ (high air speeds) to exceeding even $10 \mathrm{~mm}$ (low air speeds; Raschke, 1960) and its characteristics are strongly dependent on the local flow field around the leaf. With respect to scalar transfer, the boundary layer actually isolates the leaf to some extent from the ambient environment. Convective scalar transfer from (leaf) surfaces is usually represented in a similar way as conductive transfer, namely by means of a scalar difference and a resistance, i.e., the boundary-layer resistance. Its inverse, the boundary-layer conductance, is however mostly used, and is usually represented by convective heat and mass transfer coefficients, i.e., CHTCs and CMTCs, respectively $\left(h_{h}\left[\mathrm{~J} \mathrm{~s}^{-1} \mathrm{~m}^{-2} \mathrm{~K}^{-1}\right]\right.$ and $\left.h_{m}\left[\mathrm{~s} \mathrm{~m}^{-1}\right]\right)$. These convective transfer coefficients (CTCs) relate the convective heat or mass fluxes normal to the surface $\left(q_{c, w}\left[\mathrm{~J} \mathrm{~s}^{-1} \mathrm{~m}^{-2}\right]\right.$ and $\left.g_{c, w}\left[\mathrm{~kg} \mathrm{~s}^{-1} \mathrm{~m}^{-2}\right]\right)$ to the difference between the surface (wall) temperature $\left(T_{w}\left[{ }^{\circ} \mathrm{C}\right.\right.$ or $\left.\left.\mathrm{K}\right]\right)$ or vapour pressure at the surface $\left(p_{v, w}[\mathrm{~Pa}]\right)$ and a reference temperature $\left(T_{\text {ref }}\left[{ }^{\circ} \mathrm{C}\right.\right.$ or $\left.\left.\mathrm{K}\right]\right)$ or vapour pressure $\left(p_{v, r e f}[\mathrm{~Pa}]\right)$, for example the approach flow conditions:

$$
\begin{gathered}
h_{h}=\frac{q_{c, w}}{T_{w}-T_{r e f}} \\
h_{m}=\frac{g_{c, w}}{p_{v, w}-p_{v, r e f}}
\end{gathered}
$$

The convective fluxes are assumed positive away from the surface. Although mostly CTCs are reported, the boundary-layer conductance (BLC) is also sometimes used, which is defined as $g_{b, h}=h_{h} / \rho c_{p}\left[\mathrm{~m} \mathrm{~s}^{-1}\right]$ for heat transfer, and as $g_{b, m}=h_{m} R_{v} T$ [m s ${ }^{1}$ ] for mass transfer, where $R_{v}$ is the specific gas constant of water vapour $\left[\mathrm{J} \mathrm{kg}^{-1} \mathrm{~K}^{-1}\right]$ and $T$ is the temperature in Kelvin.

CTCs are usually presented as correlations with the air speed (forced convection) or with a temperature difference (natural convection). These correlations are often expressed in dimensionless numbers (see section 3), i.e., correlating the Nusselt ( $\mathrm{Nu}$ ) or Sherwood number $(S h)$ to the Reynolds $(R e)$ or Grashof number $(\mathrm{Gr})$, which are defined as:

$$
\begin{aligned}
& N u=\frac{g_{b, h} L_{r e f}}{\alpha}=\frac{h_{h} L_{r e f}}{k} \\
& S h=\frac{g_{b, m} L_{r e f}}{D_{v}}=\frac{h_{m} L_{r e f}}{\frac{D_{v}}{R_{v} T}} \\
& \operatorname{Re}=\frac{U_{r e f} L_{r e f}}{v}
\end{aligned}
$$


$G r=\frac{\beta g\left(T_{w}-T_{r e f}\right) L_{r e f}^{3}}{v^{2}}$

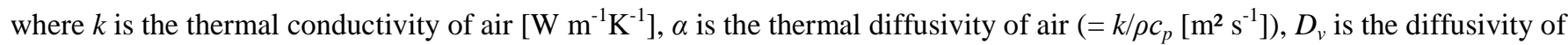
water vapour in air $\left[\mathrm{m}^{2} \mathrm{~s}^{-1}\right], L_{r e f}$ is a reference length scale [m], e.g., the length of the leaf, $U_{\text {ref }}$ is a reference air speed $\left[\mathrm{m} \mathrm{s}^{-1}\right], \beta$ is the thermal volumetric expansion coefficient of air $\left[\mathrm{K}^{-1}\right], T_{w}$ is the leaf surface temperature $[\mathrm{K}], T_{\text {ref }}$ is a reference temperature $[\mathrm{K}]$ and $v$ is the kinematic viscosity of air $\left[\mathrm{m}^{2} \mathrm{~s}^{-1}\right]$.

Note that Eqs.(1-2) rather define the CTCs instead of specifying them as known information on the surface boundary (Lienhard and Lienhard, 2006) as CTCs are actually a simplified way to represent a complex scalar transfer problem in the boundary layer and the surrounding flow field. As such, CTCs are not necessarily constant in space or time. In the following paragraphs, different aspects of convective scalar exchange for leaves are discussed, with specific focus to those that are relevant for prediction of CTCs.

\subsection{Air flow}

Air flow is a prerequisite for convective exchange. Leaves are not isolated but form a part of a more complex plant assembly (e.g., a plant in a canopy), resulting in a very complex, case-specific air flow field around them. Both outdoor (e.g., forest or orchard) and indoor (e.g., greenhouse or cooling/storage rooms), different flow regimes can be found, depending on the importance of inertial forces, caused by external pressure differences (e.g., wind), compared to buoyancy forces, caused by temperature-induced density variations: forced, natural and mixed convection may exist. With forced convection due to wind or fan-forced air flow, heat acts as a passive scalar, thus not influencing the flow field. With natural and mixed convection, heat acts as an active scalar, making the flow field dependent on the thermal conditions. In all regimes, flow around leaves usually is (or becomes) turbulent for sufficiently large leaves, due to high air speeds or thermal instabilities. With respect to turbulent boundary layers, the convective transfer in the lower part of the boundary layer is particularly important (i.e., in the viscous sublayer) since laminar flow occurs here and the majority of the boundary-layer resistance is present (Defraeye et al., 2010). Flow within plant assemblies and at leaf surfaces is however very case-specific since it is influenced by the plant species, the air flow and thermal conditions, the turbulence characteristics, the leaf area density, the leaf inclination, the interaction between different leaves of a single plant but also between plants themselves, etc. As such, it is difficult to discuss or classify air flow patterns in plant canopies and on leaf surfaces in a generalised way. Some examples of studies looking at such air flow distributions can be found in Mochida et al. (2008), Melese Endalew et al. (2010a, 2011) or Dupont et al. (2011, 
Defraeye T., Verboven P., Ho Q.T., Nicolai B., Convective heat and mass exchange predictions at leaf surfaces: applications, methods and perspectives, Computers and Electronics in Agriculture 96, 180-201. http://dx.doi.org/10.1016/j.compag.2013.05.008

2012) for plant canopies, and in Gates and Benedict (1963), Grace and Wilson (1976), Kitano and Eguchi (1987a, 1987b, 1990) and Roth-Nebelsick (2001) for leaf boundary layers.

Boundary-layer flow along the leaf surface is influenced by different types (and scales) of surface roughness: (1) the leaf's vascular structure, i.e., the veins; (2) trichomes (also called epidermal hairs); (3) microscale lobes, including the presence of stomata. These structures are located within the viscous sublayer, but can also protrude from it. They can enhance heat and mass transfer (decrease the boundary-layer resistance) by increasing turbulence production (Parkhurst, 1976; Schreuder et al., 2001; Benz and Martin, 2006). On the other hand, a dense trichome distribution can induce a quasi-stagnant air layer, in which heat and mass transport is mainly diffusion-based, leading to an increased boundary-layer resistance (Wuenscher 1970; Meinzer and Goldstein, 1985; Schuepp, 1993). Surface roughness can also enhance heat transfer by an increase of the effective surface area: e.g., trichomes can act similar to cooling fins. As mass transfer predominantly occurs at specific sites on the leaf surface (stomata, as discussed below), it will not directly be enhanced by a roughness-induced surface area increase. A particular exception is the formation of gas films during submergence on hydrophobic leaf surfaces due to microstructural morphology and wax structure and properties: here the gas film has been shown to effectively increase the contact surface between the leaf air spaces and the surrounding water (Pedersen and Colmer, 2012). Note that the presence of surface roughness, thus its impact on convective transfer, is very species-specific.

\subsection{Heat and mass balance at the leaf surface}

Apart from convection, heat transfer at leaf surfaces is also determined by other heat flows in the leaf heat balance, namely radiation, conduction and evaporation (Figure 1), of which the magnitude varies depending on the environmental conditions. With respect to conductive transfer, the leaf temperature over its thickness is often considered quasi constant, i.e., with no or small temperature gradients, as the leaf thickness is typically a few 100 microns (Nobel, 2005; Jayalakshmy and Philip, 2010). In the lateral direction however, distinct temperature gradients can be noticed across the leaf due to the rather low thermal conductivity $\left(\sim 10^{-1} \mathrm{~W} \mathrm{~m}^{-1} \mathrm{~K}^{-1}\right)$, which is similar to water, i.e., the main constituent of a leaf, next to air and biological material. The thermal capacity $\left(\sim 10^{3} \mathrm{~J} \mathrm{~kg}^{-1} \mathrm{~K}^{-1}\right)$ lies below that of water, but is rather high for a solid material (Jayalakshmy and Philip, 2010). Nevertheless, little heat can be stored in leaves due to their limited mass, by which their response to heating/cooling is rather fast, compared to other plant organs such as fruit. Furthermore, both long-wave and short-wave (solar) radiation are present at the leaf surface, on which more details can be found in Lambers et al. (2008), amongst others. Finally, evaporation requires latent heat for the phase change from liquid water to vapour and is inherently related to transpiration, thus to convective mass transfer, which is discussed in the next paragraph. 
Defraeye T., Verboven P., Ho Q.T., Nicolai B., Convective heat and mass exchange predictions at leaf surfaces: applications, methods and perspectives, Computers and Electronics in Agriculture 96, 180-201. http://dx.doi.org/10.1016/j.compag.2013.05.008

Mass transfer at leaf surfaces involves mainly $\mathrm{H}_{2} \mathrm{O}, \mathrm{CO}_{2}$ and $\mathrm{O}_{2}$, and the corresponding mass balances only contain two terms: mass diffusion from/into the leaf and convective exchange with the environment (Figure 1). For water, the transpiration rate thus equals the convective water loss. From the intercellular air spaces in the leaf, mass is transported to the leaf surface via the epidermis, i.e., via both cuticle and stomata, and from thereon to the environment via the boundary layer. As the cuticular resistance is very large, transport occurs mainly via stomata. Stomata have sizes of a few tens of micron and compose about one to a few percent of the leaf surface area, with a density of $10^{1}-10^{2}$ per $\mathrm{mm}^{2}$ (e.g., Nobel, 2005), which can differ for upper (adaxial) and lower (abaxial) leaf surface. Stomatal resistance is mainly determined by the stomatal opening. The stomatal regulatory system is a complex function of, amongst others, plant water availability (turgor pressure), photosynthetic rate, solar radiation, water vapour pressure, temperature or even air pollution (Mansfield, 1998) and although many aspects have been clarified, it is not yet fully understood (Nobel, 2005). As mass transport occurs almost solely via the stomata, a very heterogeneous mass exchange pattern is found on the leaf surface (Haseba, 1974). Although the exact location where water evaporates in a leaf is still open (Cannon et al., 1979; Holbrook and Zwieniecki 2005), it is likely to occur in the proximity of the stomata, i.e., near the substomatal cavities, by which the air in these cavities is nearly saturated (Nobel, 2005). The heterogeneous nature of the evaporation locations within the leaf also results in heterogeneous heat transport within the leaf. Accounting for such heterogeneous heat and mass boundary conditions can be quite challenging for experimental and numerical studies, and will be discussed more in detail in section 3.

Both for heat and mass transfer, the other fluxes in the total balances (e.g., heat or mass diffusion in leaf) determine whether accurate convective heat/mass transfer predictions (CHTCs and CMTCs), both in space and in time, are required for a reliable assessment of the heat/mass transport in/form the leaf: e.g., the stomatal resistance can become much larger than the convective boundary-layer resistance, for example at high air speeds (high CMTCs), by which it dominates the mass exchange with the environment and thus less detailed knowledge on the CMTC is needed (Cannon et al., 1979). The importance of convection (boundary-layer resistance) on the heat/mass flow from leaf surfaces is thus also dependent on the flow regime (forced, natural or mixed), and becomes smaller at higher air speeds (CTCs). More information on the magnitude of these resistances can be found in several textbooks (e.g., Nobel, 2005; Lambers et al., 2008).

\subsection{Time scales}

Finally, one should acknowledge that different time scales are involved with convective exchange: (1) turbulence in the air flow around the leaf $\left(\sim 10^{0}-10^{1} \mathrm{~Hz}\right.$; Schuepp, 1980); (2) leaf flutter $\left(\sim 10^{0}-10^{1} \mathrm{~Hz}\right.$; Shive and Brown, 1978; Roden and Pearcy, 
Defraeye T., Verboven P., Ho Q.T., Nicolai B., Convective heat and mass exchange predictions at leaf surfaces: applications, methods and perspectives, Computers and Electronics in Agriculture 96, 180-201.

http://dx.doi.org/10.1016/j.compag.2013.05.008

1993); (3) thermal response of leaves to temperature changes, related to the thermal inertia/capacity $\left(\sim 10^{1} \mathrm{~s}\right.$; Leigh et al., 2006 ; Vogel, 2009); (4) dynamics of stomatal opening ( 101 min; Mott and Buckley, 2000; Nobel, 2005; Marenco et al., 2006); (5) sap flow in leaf veins $\left(\sim 0.1 \mu \mathrm{m} \mathrm{s}^{-1}\right.$; Cermak et al., 2002, $100 \mu \mathrm{m} \mathrm{s}^{-1}$ during dehydration-rehydration; Kim and Lee, 2010). The particular time scales of interest determine the type of experiment (or simulation) to be performed. Also, some processes can be considered steady state compared to others by which they can be decoupled: e.g., the dynamics of stomatal opening can be considered quasi steady compared to the turbulent flow around a leaf.

\section{Methods}

As mentioned in section 2, convective transfer at leaf surfaces is usually represented by means of CTCs. Although CTCs represent convective exchange in a rather simplified way, they are useful parameters to quantify, compare and predict the rate with which heat or mass are transferred convectively from the leaf to the environment. Hence, CTCs are often used to estimate the convective transfer in leaf heat/mass balances or to compare different factors influencing convective transfer in a straightforward way. CTCs can be determined analytically, experimentally or numerically, and these different methods are discussed below, including real, artificial as well as virtual leaf sensors. Note that the applications for which these methods are applied, which are listed in section 1, are not discussed in detail, as the focus of this study was mainly on the methods themselves.

\subsection{Analytical methods}

Convective transfer predictions for leaves have often been based on CTC- $U_{\infty}$ correlations for flow parallel along a flat plate, where $U_{\infty}$ is the free-stream air speed $\left(\mathrm{m} \mathrm{s}^{-1}\right)$. These correlations have been obtained analytically for laminar flow, or (semi)empirically for turbulent flow, by using information of wind-tunnel experiments (e.g., Lienhard and Lienhard, 2006). Some of these flat-plate correlations were based on the analogy between momentum and heat/mass transfer, thus only using empirical information on the flow field. Such correlations can be found in several textbooks, as a flat plate is a basic configuration in fluid dynamics. Typical correlations for heat transfer for forced-convective laminar flow and turbulent flow, assuming a constant plate temperature, are, respectively (Lienhard and Lienhard, 2006):

$$
\begin{aligned}
& N u_{x}=0.332 \operatorname{Pr}^{1 / 3} \operatorname{Re}_{x}^{1 / 2} \\
& N u_{x}=0.032 \operatorname{Pr}^{0.43} \operatorname{Re}_{x}^{0.8}
\end{aligned}
$$

$N u_{x}$ is the Nusselt number, based on the distance along the plate $(x[\mathrm{~m}]), \operatorname{Pr}$ is the Prandtl number of air and $R e_{x}$ is the Reynolds number, based on $x$ and $U_{\infty}$. Note that these equations assume transfer from one side of the plate, whereas leaves 
Defraeye T., Verboven P., Ho Q.T., Nicolai B., Convective heat and mass exchange predictions at leaf surfaces: applications, methods and perspectives, Computers and Electronics in Agriculture 96, 180-201.

http://dx.doi.org/10.1016/j.compag.2013.05.008

exchange heat from both sides. Most flat-plate CTC- $U_{\infty}$ correlations were determined for heat transfer, for plates heated at a constant temperature. The convective transfer predictions are, however, to some extent dependent on the applied (thermal) boundary conditions, i.e., constant temperature or heat flux. In general, both boundary conditions result in nearly identical CHTCs (differences of a few percent) for turbulent flow (Siegel and Sparrow, 1960; Cebeci and Bradshaw, 1984; Kays and Crawford, 1993), since the major part of the thermal resistance is located in the thin viscous sublayer, which is quite independent of the upstream history of the flow (Lienhard and Lienhard, 2006). However, near the leading edge and particularly at low Reynolds numbers (i.e., laminar flow), Nusselt numbers differ much more (>10\%, Siegel and Sparrow, 1960; Cebeci and Bradshaw, 1984; Taylor et al., 1989; Kays and Crawford, 1993).

Both boundary conditions for heat transfer differ from those found for real leaves. A constant temperature condition is definitely considered unrealistic. Also, although leaves can receive a quasi constant heat flux (e.g., by solar radiation), it is not balanced by the convective flux alone as also conduction and long-wave radiation contribute. Thus, a constant flux condition does also not occur (Murphy and Knoerr, 1977), but it is considered a more realistic condition for leaves (Parlange et al., 1971; Wigley and Clark, 1974; Schuepp, 1993; Vogel, 2009). The impact of these thermal boundary conditions on the CTCs is however often considered limited for leaves (Schuepp, 1993). Note that Kays and Crawford (1993) proposed a superposition method to determine the CHTCs along flat plates with an arbitrary heat flux or temperature distribution along the plate.

Although the difference between these two types of boundary conditions is also limited for mass transfer (Cowan, 1972), none of them are realistic since mass exchange occurs predominantly via the discretely-distributed microscopic stomata, thus only at a small part of the leaf surface instead of at the entire surface. As a result, flat-plate correlations can in principle not be applied to estimate CMTCs for leaves, due to the heterogeneous scalar boundary conditions. However, Schlünder (1988) investigated this phenomenon and showed (analytically) that for laminar boundary-layer flow over a flat surface, a relatively high mass flow rate could be maintained for a partially-wetted surface, as the surface actually behaves very similar to a uniformly-wetted surface. Furthermore, CMTCs are often estimated from CHTCs by using the heat and mass transfer analogy (Chilton and Colburn, 1934), which only applies under strict conditions (no radiation, no coupling between heat and mass transfer, analogous boundary conditions, etc.). Thereby, it cannot be used in principle for leaves as the conditions for heat and mass transfer differ. Nevertheless, this analogy is applied regularly.

Apart from the aforementioned issues, these flat-plate correlations all somehow lack physical similarity regarding the flow pattern, as flow along a leaf and its turbulence content/intensity are considerably different, amongst others due to leaf 
Defraeye T., Verboven P., Ho Q.T., Nicolai B., Convective heat and mass exchange predictions at leaf surfaces: applications, methods and perspectives, Computers and Electronics in Agriculture 96, 180-201. http://dx.doi.org/10.1016/j.compag.2013.05.008

inclination and edge effects. Flat plates are also assumed long in the streamwise and spanwise direction, by which they are actually not representative for leaves. Furthermore, correlations are often only available for forced or natural convective flow, but the intermediate regime (mixed convection), is usually not covered, although very relevant for leaves. In addition, it is also difficult to obtain a reliable estimate of $U_{\infty}$, being "some" undefined air speed near the leaf, and usually the exact location where $U_{\infty}$ is evaluated, is chosen in a rather arbitrary way. The complexity is even increased since significant air speed gradients exist in the atmospheric boundary layer over the height, particularly within plant canopies (e.g., Blocken et al., 2007; Melese et al., 2011).

Nevertheless, a lot of valuable information on CTCs was obtained from flat-plate experiments, for example on the influence of surface roughness, and the obtained correlations were for a long time considered sufficient for practical purposes. These correlations are also used frequently in an indirect way: convective transfer from leaves is quantified by multiplying the righthand side of Eq.(7) or Eq.(8) with an empirically-determined correction factor $(\beta)$ which accounts for the difference with a flat plate. This factor is usually 2 or 2.5 (e.g., Parlange et al., 1971; Wigley and Clark, 1974; Grace and Wilson, 1976), as will become clear in the next section.

\section{$\underline{3.2 \text { Experimental methods }}$}

Convective transfer can also be measured experimentally on real leaves or leaf models, instead of on large flat plates parallel to the air flow (see section 3.1). These experiments can be subdivided into laboratory experiments (e.g., in a wind tunnel) and field experiments (e.g., in a canopy). Before discussing both types (section 3.2.2 and 3.2.3), the techniques to quantify convective heat and mass transfer with real leaves or artificial leaves are dealt with first.

\subsubsection{Real vs. artificial leaves}

Quantifying convective heat or mass transfer from leaf surfaces in laboratory setups or in the field is done using two different sensors: real leaves or artificial leaves. The measurement techniques/methods for both sensor types are briefly described and compared below. Real leaves which have been modified, such as with a wire mesh (e.g., Murphy and Knoerr, 1977) or a coating (e.g., Martin et al., 1999), are included with the techniques for artificial leaves. The term "leaf" also covers branches of coniferous species. For more detailed information, the reader is referred to the literature cited.

\section{$\underline{\text { Real leaves }}$}

For real leaves, the following techniques are used for convective heat transfer measurements: 
Defraeye T., Verboven P., Ho Q.T., Nicolai B., Convective heat and mass exchange predictions at leaf surfaces: applications, methods and perspectives, Computers and Electronics in Agriculture 96, 180-201. http://dx.doi.org/10.1016/j.compag.2013.05.008

- Heat balance method (HBM). The CHTC is determined from the leaf heat balance by estimating all other heat flows in the balance (e.g., short-wave radiation with pyranometer, transpiration with photometer, etc.) (Knoerr and Gay, 1965; Sinclair, 1970; Kumar and Barthakur, 1971; Parlange et al., 1971; Saldin and Barthakur, 1971; Parlange and Waggoner, 1972; Kitano and Eguchi, 1989; Martin et al., 1999; Roy et al., 2008).

- Heat balance method - two states (HBM-TS). As the HBM, the CHTC is determined from the leaf heat balance by estimating all other heat flows in the balance. However, the heat balance is determined for two states, usually with and without transpiration, mostly by using pairs of leaves. From these two balances, an unknown heat flow can be eliminated, hence avoiding its direct measurement, as is done in the HBM. Mostly short-wave radiation is eliminated since it is often difficult to measure in the field. Transpiration can be supressed, for example, by applying Vaseline ${ }^{\circledR}$ coating (Thorpe and Bulter, 1977) or by antitranspirants, which induce turgor loss in guard cells and thus stomatal closure (Kitano et al., 1995). The accuracy of this method can be compromised if radiation on both leaves is not the same (e.g., due to sunflecks) by which corrections are necessary (Brenner and Jarvis, 1995).

- Cooling curve technique (CCT). The leaf is initially heated to a certain temperature after which it is allowed to cool down. With this transient technique, the amount of heat convected away from the leaf is estimated from the cooling curve (Pearman, 1965; Kumar and Barthakur, 1971; Parlange et al., 1971; Saldin and Barthakur, 1971). Note that also the inverse technique can be applied, i.e., where the leaf is cooled initially (Michaletz and Johnson, 2006).

- Schlieren photography technique (SPT). Convective transfer is calculated from the size of the convective plume, obtained from Schlieren photographs, and the temperature of the plume. This technique provides quantitative information, but it is less suitable for forced convection, since the convective plume is less pronounced here (Gates and Benedict, 1963).

For convective mass transfer measurements, the following techniques are used:

- Weighing method (WM). Transpiration of leaves (or of a plant, i.e., multiple leaves), thus the convective mass loss, is measured gravimetrically. This technique is usually used for entire plants (Kumar and Barthakur, 1971; Dixon and Grace, 1984; Kitano and Eguchi, 1989; Kitano et al., 1995; Kichah et al., 2012).

- Potometer method (PM). Transpiration of a leaf is measured by a potometer, connected to the leaf, with which the amount of water uptake is measured. This technique is similar to the weighing method, but is rather used for single leaves or branches (Sinclair, 1970).

- Heat balance method - two states for mass transfer (HBM-TS-M). A similar technique as HBM-TS, discussed above, but now the heat balance is solved to the transpiration rate (Leuning and Foster, 1990). 
Defraeye T., Verboven P., Ho Q.T., Nicolai B., Convective heat and mass exchange predictions at leaf surfaces: applications, methods and perspectives, Computers and Electronics in Agriculture 96, 180-201. http://dx.doi.org/10.1016/j.compag.2013.05.008

- Ventilated chamber technique (VCT). The transpiration rate (thus convective mass loss) is determined from the water vapour pressure difference between incoming and outgoing air in the ventilated chamber (Leuning and Foster, 1990).

- $\quad$ Resistance substraction method (RSM). The boundary-layer resistance is determined from the difference between the total leaf resistance to vapour transport and the stomatal resistance, measured with a porometer (Meinzer et al., 1993; Martin et al., 1999).

- Hanging tree technique (HTT). An entire tree is cut and is suspended on a load cell. Afterwards, the tree is wetted by spraying water on it, until saturated, and is allowed to dry. By monitoring the weight change, the boundary-layer conductance of the entire tree is obtained (Teklehaimanot and Jarvis, 1991; Smith et al., 1997b).

Specific drawbacks are inherent to the use of real leaves: (1) Real leaves will flutter, unless they are fixed. Flutter can have a large impact on convective transfer (Schuepp, 1972) but some studies found a more limited impact (Parkhurst et al., 1968; Parlange et al., 1971), indicating the complex and case-specific nature of flutter on convective transfer, i.e., dependent on the flow field, turgor pressure of the leaf, etc.; (2) Stomatal opening and its dynamics show a complex dependency on several influence factors (e.g., turgor pressure), and are difficult to control or to monitor. They however have a large effect on the convective mass (and heat) exchange; (3) Intraspecies variability of leaves, i.e., every leaf is different, introduces variability on the results and makes repeatability difficult. These drawbacks introduce a variability and uncertainty on CTCs obtained with real leaves.

\section{$\underline{\text { Artificial leaves }}$}

Artificial leaves (also called model, replica or surrogate leaves) are often preferred instead of real leaves in experiments, mainly to avoid aforementioned drawbacks: leaf flutter can be avoided (or controlled), stomatal opening and its dynamics are not relevant anymore and sensor uniformity reduces variability (e.g., with respect to leaf shape) and ensures repeatability. Such artificial leaves can be given a realistic shape, but also simplified shapes (e.g., elliptical) are used. They are often designed, calibrated and/or tested by means of laboratory setups, prior to their use in the field. Different measurement techniques were developed in the past, often similar to those of real leaves, resulting in several types of artificial leaf sensors.

For convective heat transfer measurements, the following techniques are used:

- Heat balance method (HBM). This technique is similar as described above. The artificial leaf is often heated from the exterior (e.g., radiation) or from the interior (embedded heating element), introducing an additional term in the heat balance (Parkhurst et al., 1968; Thom, 1968; Sinclair, 1970; Vogel, 1970; Pearman et al., 1972; Parkhurst and 
Defraeye T., Verboven P., Ho Q.T., Nicolai B., Convective heat and mass exchange predictions at leaf surfaces: applications, methods and perspectives, Computers and Electronics in Agriculture 96, 180-201.

http://dx.doi.org/10.1016/j.compag.2013.05.008

Pearman, 1974; Wigley and Clark, 1974; Iqbal and Stoffers, 1975; Balding and Cunningham, 1976; Murphy and Knoerr, 1977; Morrison and Barfield, 1981; Gottschlich and Smith, 1982; Dixon and Grace, 1983; Chen et al., 1988a, 1988b; Kitano and Eguchi, 1990; Bailey and Meneses, 1995).

- Heat balance method - two states (HBM-TS). This technique is similar as described above, but now the two states are usually with and without leaf heating, using a pair of leaves. To avoid compromising the accuracy of the method by unequal radiation on both leaves (e.g., due to sunflecks), Daudet et al. (1998) proposed an alternative, which used concentrically heated and unheated surfaces within the same leaf, instead of using paired leaves. Another issue with paired leaves is that the flow field around the unheated leaf (thus the CHTC) will be different from the heated leaf at high heating rates, due to buoyancy effects. Therefore, low heating rates are advised (Tibbals et al., 1964; Pearman et al., 1972; Silva et al., 1988; Leuning and Foster, 1990; Brenner and Jarvis, 1995; Domingo et al., 1996; Smith et al., 1997b; Daudet et al., 1998, 1999; Grantz and Vaughn, 1999; Stokes et al., 2006).

- $\quad$ Cooling curve technique (CCT). This technique is similar as described above (Gates et al., 1965; Linacre, 1967; Pearman et al., 1972; Grace et al., 1980; Schuepp, 1980; Dixon and Grace, 1984).

- Heat flux method (HFM). The CHTC is directly determined from measurements of leaf surface temperature and the heat flux, from a heat flux plate (Schuepp, 1980).

For convective mass transfer measurements, the following techniques are used:

- Water loss technique (WLT). An artificial leaf is wetted and is weighed before (sometimes during) and after the experiment. The CMTC is determined from the mass loss and the (saturation) vapour pressure at the surface. These leaves were mostly made out of blotting/filter paper (Landsberg and Powell, 1973; Grace and Wilson, 1976; Schuepp, 1980; Thom, 1968; Roberts et al., 1990; Brenner and Jarvis, 1995) but also real leaves covered with a nylon mesh (Murphy and Knoerr, 1977) and real leaves/branches coated with plaster (Landsberg and Ludlow, 1970; Martin et al., 1999) were used.

- $\quad$ Potometer method (PM). This technique is similar as described above, but now an artificial leaf, e.g., made out of filter paper, is used. The difference with the WLT is that a continuous supply of water is available (Grantz and Vaughn, 1999).

- Ventilated chamber technique (VCT). This technique is similar as described above, but now an artificial leaf, e.g., made out of filter paper, is used (Landsberg and Ludlow, 1970). 
Defraeye T., Verboven P., Ho Q.T., Nicolai B., Convective heat and mass exchange predictions at leaf surfaces: applications, methods and perspectives, Computers and Electronics in Agriculture 96, 180-201.

http://dx.doi.org/10.1016/j.compag.2013.05.008

- $\quad$ Heat balance method for mass transfer (HBM-M). This technique is in principle the HBM, described above, but now a transpiring artificial leaf is used. The CMTC is determined from the heat balance, which now also includes heat of evaporation (Chen et al., 1988b).

- $\quad$ Electrochemical method (ECM). Here, a reacting electrolyte is added in a low concentration to a non-reacting electrolyte and convective transfer of ions towards an electrode, representing the leaf, is measured. The CMTC is calculated from measured electric currents. Since a fluid (not air) is used, the obtained CMTCs should be scaled to be representative for real leaves in air (Schuepp, 1972; Schuepp, 1973; Gurevitch and Schuepp, 1990).

- $\quad$ Naphthalene sublimation technique (NS). This technique is often used to measure CMTCs (Neal, 1975; Barlow and Belcher, 2002; Barlow et al., 2004) and was suggested by Brenner and Jarvis (1995) for leaves, but it was not yet used for this purpose.

Specific drawbacks are inherent to the use of artificial leaves. With respect to convective heat transfer a mismatch in thermal boundary conditions is often present between artificial and real leaves: metallic artificial leaves have a uniform temperature distribution across the leaf due to their high thermal conductivity. For real leaves however, a constant flux condition is more representative (see section 3.1). The resulting CHTCs thus also differ for both cases as boundary-layer development and edge effects are different. Iqbal and Stoffers (1975) found CHTC differences below 15\%. To obtain more realistic temperature distributions across artificial leaves, Vogel (1970) proposed local heating in the centre of the leaf and Stokes et al. (2006) proposed the use of a non-metallic artificial leaf, made from Mylar ${ }^{\circledR}$. Nevertheless, a mismatch in thermal boundary conditions will always exists since latent heat of evaporation at the stomata, due to transpiration, is not accounted for, but results in very heterogeneous boundary conditions at microscale level. Furthermore, artificial leaves often have a different reflectivity and emissivity than real leaves, which can however be optimised by painting or polishing the surface. Also, the surface roughness of artificial leaves is usually much smaller than that of real leaves: smooth, metallic surfaces were mostly considered, without microscale roughness (trichomes or microscale lobes), but also without venation.

With respect to convective mass transfer experiments on artificial leaves, drawbacks are also present. First, a homogeneous (mostly uniform) mass transfer boundary condition is applied over the artificial leaf surface, e.g., completely wet filter paper. This boundary condition differs from reality, as mass transfer predominantly occurs via the stomata, which are distributed heterogeneously over the leaf surface and only occupy a small percentage (few percent) of the surface area (section 2). Some studies tried to mimic the effect of these discrete sources on the convective mass transfer (Haseba, 1974; Cannon et al., 1979). Differences were found with uniformly wetted flat plates, and the convective transfer was dependent on size, spacing and 
Defraeye T., Verboven P., Ho Q.T., Nicolai B., Convective heat and mass exchange predictions at leaf surfaces: applications, methods and perspectives, Computers and Electronics in Agriculture 96, 180-201.

http://dx.doi.org/10.1016/j.compag.2013.05.008

density of these sources. Since the stomatal opening (resistance) also varies over the leaf surface and over time (Wigley and Clark, 1974), the boundary conditions become even more complicated, and almost impossible to mimic with an artificial leaf sensor. This mismatch in mass transfer boundary conditions, compared to real leaves, compromises attempts to model the coupled heat and mass transfer realistically with artificial leaves. Second, in real leaves, heat transfer is strongly coupled with mass exchange via the stomata, and vice versa, since the vapour pressure at the leaf surface is temperature dependent. Artificial leaf sensors, however, mostly only account for heat transfer instead of such coupled heat and mass transfer. Including transpiration in artificial leaf design (e.g., Morrison and Barfield, 1981) could alleviate this partially. Third, experiments to measure CMTCs are often argued to be less straightforward and less accurate than CHTC measurements (Ben Nasrallah and Perre, 1988; Belhamri and Fohr, 1996; Iskra et al., 2009), which is why CMTCs are often estimated from CHTCs, using the heat and mass transfer analogy (e.g., Defraeye et al., 2011). Inaccuracies originate mainly from weighing (WLT, PM, NS) or determining water vapour pressure differences (VCT). The HBM-M, proposed by Chen et al. (1988b), is argued to provide a higher accuracy as it only relies on heat transfer measurements. Finally, for continuous use in the field, thus for longer time periods, some mass transfer techniques (WLT, ECM, NS) cannot be used (Brenner and Jarvis, 1995).

The aforementioned research has led to the development of several artificial leaf sensors for online monitoring of CHTCs in the field (indoor and outdoor). Although some practical problems were reported earlier (Brenner and Jarvis, 1995) for continuous use in the field, they have been largely solved, and boundary-layer conductance sensors are commercially available (see Figure 2).

\subsubsection{Field experiments}

Field experiments have often been used to determine CTCs for leaves, particularly since the environmental conditions and leaf/plant microclimate are realistic. Such field experiments have been carried out both outdoor, i.e., in tree or crop canopies, and indoor, i.e., in a greenhouse, and using both artificial as well as real leaves. In Table 1, a non-exhaustive overview on past field experiments on convective transfer from leaves is presented. The symbols, parameters and abbreviations used in this table, and in following tables, are given in Table 2. For some studies, only the most relevant correlations are included due to space limitations but the remainder can be found in the original publications. No distinction is made between natural, mixed and forced convection since this is not straightforward for field experiments, and the conditions often change during the measurements. Following remarks can be made with respect to Table 1: 
Defraeye T., Verboven P., Ho Q.T., Nicolai B., Convective heat and mass exchange predictions at leaf surfaces: applications, methods and perspectives, Computers and Electronics in Agriculture 96, 180-201. http://dx.doi.org/10.1016/j.compag.2013.05.008

- Heat transfer experiments are preferred instead of mass transfer experiments, and the HBM and HBM-TS are most popular. The VCT can be considered rather unrealistic for outdoor environments since the microclimate in the chamber is different from that of the surrounding plants in the canopy.

- Real leaves are usually allowed to flutter whereas artificial leaves are mostly fixed.

- Outdoor experiments are performed predominantly, instead of in greenhouses.

- Mostly broad leaves are used instead of coniferous species.

- Both linear and power-law correlations are reported. Several correlations include an intercept (i.e., at $U=0 \mathrm{~m} \mathrm{~s}^{-1}$ ) to account for buoyancy effects at low air speeds.

- The boundary-layer conductance is preferred to express the correlations instead of the Nusselt number (CHTC).

Field experiments however have some restrictions. They provide realistic CTCs, but these CTCs are strongly related to the specific flow field around the leaf, which is dependent on leaf orientation, plant species, leaf area density (seasonal variation), canopy density, canopy surroundings, air flow characteristics (turbulence, wind direction, etc.), thermal conditions (solar radiation), greenhouse geometry, measuring period (daytime or nighttime), etc. The obtained CTC predictions and correlations are consequently very case specific and not often generally applicable. Furthermore, CTCs are correlated with a certain reference air speed, such as the air speed at some distance above the canopy or inside the canopy. This air speed will be very canopy specific, and will also be difficult to relate to an air speed measured outside of the canopy, which makes the obtained correlations even less generally applicable. Finally, for field experiments, the complexity of air flow and thermal conditions, both for indoor and outdoor, is rather high and a distinct temporal variability is present at different time scales: instantaneous (leaf flutter), hourly (e.g., solar radiation, cloudiness), diurnal (day-night cycle) and even seasonal. It is thus often difficult to investigate the impact of one influence factor on the CTCs, since other influence factors also change.

\subsubsection{Laboratory experiments}

Most experimental research on convective exchange of leaves has been performed in a laboratory environment. The principal reason is that air flow and heat/mass boundary conditions can be controlled better, compared to field experiments. Hereby, the sensitivity to a single CTC influence factor can be identified more clearly, and repeatability is improved. Furthermore, more detailed data on the flow and scalar field can be obtained, both spatially and temporally, often with lower experimental uncertainties. 
Defraeye T., Verboven P., Ho Q.T., Nicolai B., Convective heat and mass exchange predictions at leaf surfaces: applications, methods and perspectives, Computers and Electronics in Agriculture 96, 180-201. http://dx.doi.org/10.1016/j.compag.2013.05.008

Several setups were used: (1) wind tunnel (or fluid tunnel); (2) assimilation chamber, which can in principle be considered as a very simplified, closed-circuit wind tunnel. Its advantage, compared to a conventional wind tunnel, is that the heat and mass flow in and out of the chamber can be measured in detail, from which the transpiration rate can be determined; (3) Münger cell (see Roy et al., 2008), which can also be considered as a closed-circuit wind tunnel, a but very small one, namely for measurements on a single leaf. It is a small container that is placed over the leaf. Controlled air flow is produced over the leaf, and air flow conditions at inlet and outlet are measured; (4) growth chamber, which is specifically designed for plants and thereby realistic environmental conditions (e.g., radiation) can be produced; (5) greenhouse setup, developed to mimic air flow conditions in greenhouses, namely free or mixed convection.

In Table 3, a non-exhaustive overview is given on past laboratory experiments. Although some studies characterised the flow over the leaf as being laminar or turbulent, such a distinction was not included in Table 3 since: (1) a clear distinction is rather difficult as the boundary layer on the leaf surface often transcends from laminar, at the leading edge, to turbulent, further downstream (Murphy and Knoerr, 1977), and the transition point is dependent on upstream flow conditions and leaf surface roughness; (2) often approach flow turbulence was not characterised; (3) an actual boundary layer is often difficult to distinguish on the leaf surface, due to the presence of separation and recirculation regions; (4) often the distinction between laminar and turbulent is made rather arbitrarily. Following remarks can be made with respect to Table 3:

- Heat transfer experiments are preferred instead of mass transfer experiments, and the HBM and HBM-TS are most popular.

- Most experiments are performed using artificial leaves.

- The wind tunnel is by far the most commonly used setup.

- Compared to engineering correlations for flat plates (section 3.1), higher CTCs are usually obtained for leaves, i.e., the $\beta$ factor is larger than 1 .

- Most studies dealt with forced or mixed convective transfer. Only few studies solely looked at natural convective transfer, i.e., where air flow is only provoked by temperature differences and not by pressure differences (e.g., in a wind tunnel).

Laboratory experiments have some restrictions. The size of the test setup is often restricted to one leaf, a branch or a single plant, and experiments on entire canopies are not feasible without scaling down. Such scaling is not possible for real leaves, but can in principle be done with artificial leaves. Thereby, aerodynamic interference effects are not, or only partially, accounted for. Despite the capability of the (artificial) sensors to investigate such interference effects, they have only been 
Defraeye T., Verboven P., Ho Q.T., Nicolai B., Convective heat and mass exchange predictions at leaf surfaces: applications, methods and perspectives, Computers and Electronics in Agriculture 96, 180-201. http://dx.doi.org/10.1016/j.compag.2013.05.008

studied by a few researchers (e.g., Schuepp, 1972; Landsberg and Powell, 1973). Consequently, air flow and CTC predictions can be very different from reality, especially for a single leaf. Furthermore, the turbulence level and spectrum in laboratory setups are often different: usually much lower turbulence levels are used, compared to those in the atmospheric boundary layer or in a greenhouse. Increased turbulence levels can however be produced artificially, e.g., in wind tunnels. Finally, intermittent (gusty) flow is usually not modelled, by which steady-state CTCs are obtained. Schuepp (1980) however showed that intermittent flow could increase transfer rates.

\section{$\underline{\text { 3.2.4 Discussion }}$}

Some issues associated with experimental methods in general still have to be addressed, in addition to those specifically related to the sensors used (discussed in section 3.2.1), and those related to field or laboratory experiments (discussed in sections 3.2.2 and 3.2.3).

CTCs are often determined at one or a few points on the leaf surface, e.g., with thermocouples. These point-wise CTC data are often not representative for the surface-averaged CTCs, which should be acknowledged when using the resulting CTC correlations. Furthermore, the heat and mass gradients over the leaf surface and the resulting local CTC variation are often not considered as CTCs are determined at a single point or lumped over the entire leaf (surface-averaged value). A more detailed CTC distribution can be useful for some applications, e.g., for microclimate assessment of the leaf boundary layer for analysis of pathogen development. A method to measure the humidity locally in the boundary layer was proposed by Kitano and Eguchi (1987a, 1987b).

A lot of valuable experimental research was performed on CTCs, and several insights were obtained on the role of different influence factors on the convective transfer. The applicability of the obtained CTCs or CTC- $U$ correlations is however often limited: those from field experiments are very case specific, and those from laboratory experiments are sometimes difficult to extrapolate to an entire plant, or a plant canopy, due to aerodynamic interference. Moreover, studies used different leaf morphologies (shape, thickness, venation), leaf orientations, surface roughness, stomatal distribution, turbulence conditions, photosynthetic capacity, water content, etc., by which intercomparison with other studies is not always feasible, or justified. In addition, a comparison is often not possible since correlations are expressed as a function of different air speeds or characteristic lengths. To illustrate such variability, several correlations of the Nusselt number $\left(N u_{D}\right.$ or $N u_{B}$, see Table 2$)$ with the Reynolds number from laboratory experiments in Table 3 are shown in Figure 3. Note that such spread is not surprising as conditions differ for different experiments. 
Defraeye T., Verboven P., Ho Q.T., Nicolai B., Convective heat and mass exchange predictions at leaf surfaces: applications, methods and perspectives, Computers and Electronics in Agriculture 96, 180-201. http://dx.doi.org/10.1016/j.compag.2013.05.008

The choice of the characteristic length scale used in CTC- $U$ correlations is not always straightforward, e.g., for highly dissected leaves or coniferous species, and different alternatives have already been proposed (e.g., Parkhurst et al., 1968; Schuepp, 1993). Furthermore, CTC- $U$ correlations for leaves are often obtained by modifying flat-plate correlations (e.g., Eqs.(3)-(4)) by using only a correction factor $(\beta)$, whereas the exponents are taken the same, i.e., 0.5 and 0.8 for laminar and turbulent flow, respectively. It is however often more appropriate to change the exponent as well as it does not necessarily have to agree with that of a flat plate, by which a better fit with the experimental data could be obtained. Finally, CTC measurements of highly dissected leaves or coniferous species is still considered challenging. Techniques have been suggested, based on plaster coating (Landsberg and Ludlow, 1970) or transient cooling of metal replicas (Tibbals et al., 1964; Gates et al., 1965), but are much less straightforward then existing techniques for broad leaves.

Due to the aforementioned issues, the use of experimentally-determined CTCs (from literature) can result in inaccurate/unreliable predictions of air-side convective heat and mass transfer for certain applications. Nevertheless, these CTCs often provide valuable information on the impact of certain influence factors (e.g., wind speed and direction) on the convective transfer rate and such advanced experiments allow to study complex and realistic leaf shapes and flow conditions. In principle, experimentally-determined CTCs should be more representative and realistic, compared to more simplified analytical methods, and can improve the estimation of convective transfer rates significantly. For this purpose, it is however imperative that the user critically verifies if a specific CTC or CTC- $U$ correlation (e.g., determined in a wind tunnel on an artificial leaf) is sufficiently representative for the conditions for which it will be applied (e.g., in the field), i.e. that it is determined under similar conditions. A viable alternative here could be numerical modelling, as discussed in the next section.

\subsection{Numerical methods}

For numerical studies on predicting air flow and scalar transfer in and around plant canopies, computational fluid dynamics (CFD) is the appropriate technique. CFD studies have already been used extensively for this purpose in agricultural and biosystems engineering, both for indoor (Boulard and Wang, 2002; Majdoubi et al., 2009; Molina-Aiz et al., 2010; Vermeulen et al., 2012; Bartzanas et al., 2013) and outdoor applications (Hiraoka, 2005; Maricle et al., 2007; Gromke et al., 2008; Mochida et al., 2008; Dupont et al., 2010, 2011, 2012; Melese Endalew et al., 2009, 2010a, 2010b, 2010c, 2011), at different spatial scales. Such studies were mostly performed at the level of the canopy, or of the tree/plant. At canopy level, individual leaves were not modelled for computational economy, but the entire canopy was represented by a porous medium, where the impact of leaves on the air flow is modelled in a lumped way by implementing source and sink terms for momentum and 
Defraeye T., Verboven P., Ho Q.T., Nicolai B., Convective heat and mass exchange predictions at leaf surfaces: applications, methods and perspectives, Computers and Electronics in Agriculture 96, 180-201.

http://dx.doi.org/10.1016/j.compag.2013.05.008

turbulence (Green, 1992; Sanz, 2003; Katul et al., 2004). The momentum sink term includes the drag exerted by the vegetation on the air flow. The turbulence source and sink terms model the generation of wake turbulence and the short-circuiting of the turbulence energy cascade due to vegetation. These source and sink terms are usually determined experimentally, by windtunnel tests or in the field (Katul et al., 2004; Molina-Aiz et al., 2006; Sase et al., 2012) and are very species-specific.

Also at tree/plant level, a porous-medium approach was applied (e.g., Hiraoka, 2005; Gromke et al., 2008). More detailed models accounted for the tree architecture by including the branches explicitly in the model, but they still applied a porous medium approach to model the ensemble of leaves around the branches (e.g., Melese Endalew et al., 2010a, 2011). To the knowledge of the authors, leaves have not been included explicitly at canopy or tree/plant level. The main restriction in this respect is the large computational cost involved when discretely modelling the individual leaves (and shoots) in the canopy.

In addition, most of these CFD modelling studies focussed on the impact of vegetation on air flow and turbulence, and only few also included heat and mass exchange processes, such as transpiration and radiation propagation (penetration, absorption and reflection) in the canopy (e.g., Boulard and Wang, 2002; Hiraoka, 2005; Majdoubi et al., 2009; Kichah et al., 2012). Here, convective transfer is often modelled by CTCs, which are taken from literature or experiments on single leaves. At leaf level, very few CFD studies have been performed with respect to scalar transfer (Roth-Nebelsick, 2001; Roy et al., 2008). In Table 4, details of these studies on individual leaves are presented. At the sub-leaf (microscale) level, only a single CFD study is known to the authors (Roth-Nebelsick et al., 2009), where the effect of stomatal crypts on transpiration was assessed.

Despite the limited amount of numerical studies at leaf and sub-leaf level, CFD has several advantages compared to experimental research in this perspective: (1) Momentum and scalar transfer can be calculated simultaneously at very high spatial and temporal resolution. Local CTC gradients over the leaf surface can thus be identified and surface-averaged CTCs are known. Unsteady scalar transfer in the boundary layer can be assessed at a very high frequency and studies at the microscale can be performed, e.g., where stomata are modelled discretely (Roth-Nebelsick et al., 2009); (2) In principle, all relevant physics for leaves can be modelled by implementation of models for, amongst others, radiation, evaporation and photosynthesis (e.g., Collatz et al., 1991; Evans et al., 2009; Tholen and Zhu, 2011), down to the microscale level. The coupled heat and mass transfer, which is inherently present in leaves, can thus be accounted for, implying that the numerical (CFD) model does not only cover the air-side transfer. As such, the numerical model can come very close in mimicking reality, with respect to heat and mass exchange with the environment; (3) No difficulties arise when evaluating highly dissected leaves or coniferous species, apart from an increased computational cost due to the small scales that have to be resolved; (4) Numerical 
Defraeye T., Verboven P., Ho Q.T., Nicolai B., Convective heat and mass exchange predictions at leaf surfaces: applications, methods and perspectives, Computers and Electronics in Agriculture 96, 180-201.

http://dx.doi.org/10.1016/j.compag.2013.05.008

studies allow clear sensitivity analysis of convective transfer to certain CTC influence factors (e.g., turbulence); (5) No scaling issues are present as CFD studies can be performed at full scale. In conclusion, by means of numerical modelling, a virtual leaf, or even plant, can be built and placed in a specific environment. Similar to artificial leaves (section 3.2), this virtual leaf can be used as a tool for several applications mentioned in section 1 .

The main drawback of CFD is that the models used, particularly the turbulence and boundary-layer modelling approaches, do not always predict the flow field with sufficient accuracy, and those modelling approaches that do, often require a very high computational cost. Particular problems can arise with the prediction of boundary-layer transition, boundary-layer separation, the size of recirculation zones (wakes) or the influence of surface roughness. More detailed information on the performance of CFD modelling for agricultural applications can be found, amongst others, in Kondjoyan (2006), Norton and Sun (2006), Verboven et al. (2006), Ambaw et al. (2012), Defraeye et al. (2012a) or Bartzanas et al. (2013). Furthermore, modelling convective exchange including several spatial (and temporal) scales (e.g., Jarvis and McNaughton, 1986), will often be compromised by the high computational cost: e.g., modelling a plant inside a plant canopy, including the individual leaves is currently very challenging, which is why the aforementioned porous-medium approach is preferred. CFD modellers will thus have to compromise between modelling accuracy and computational restrictions to time or resources. Although these limitations have restricted the use of CFD modelling of plant canopies down to a leaf level, interesting perspectives are still open to be explored on the leaf (or sub-leaf) level itself, or towards multiscale modelling.

\section{Perspectives}

This review on convective exchange of leaves with the environment indicated that a vast amount of experimental work has been performed by field and laboratory experiments, using both real and artificial leaves. Different techniques have been developed and optimised, resulting nowadays in commercial boundary-layer conductance sensors. Such sensors can be used, for example, in greenhouses where they can provide input to integrated sensor systems, which control greenhouse ventilation and irrigation. As such, they can help optimising greenhouse climate and evaluating crop water requirements. Such sensors can also be applied outdoors for similar applications in agrometeorology.

In fact, the majority of the challenges involved with experimental measurements of convective transfer have been resolved in the past. Specific challenges which are still pending here are an assessment of convective transfer at a sub-leaf level, e.g., at stomata scale, and the use of scaled sensors in laboratory experiments (e.g., a wind tunnel), which are required when 
Defraeye T., Verboven P., Ho Q.T., Nicolai B., Convective heat and mass exchange predictions at leaf surfaces: applications, methods and perspectives, Computers and Electronics in Agriculture 96, 180-201.

http://dx.doi.org/10.1016/j.compag.2013.05.008

aerodynamic interference between leaves and plants in a large canopy is of interest. Such interference occurs in reality but was rarely measured in laboratory experiments as, for simplicity, single leaves are usually considered and as large canopies are not straightforward to set up, e.g., in a wind tunnel. Scaled sensors (and canopy models) can provide an outcome here but have not been extensively explored. Including interference effects is however imperative for accurately quantifying convective transfer from leaves, as simply extrapolating results for single leaves is not always straightforward nor justified.

Future developments and progress are rather expected for numerical methods, based on air-side transfer (CFD) simulations: although CFD is used extensively in biosystems engineering to model vegetation, it was rarely applied to study convective transfer on a leaf and sub-leaf level, despite its capability of modelling the relevant phenomena. This recent increase in the use of numerical modelling opens possibilities towards the development of a virtual leaf model. Such virtual sensors could, within a CFD simulation context, be used as an alternative to the commercial boundary-layer sensors mentioned above for greenhouse climate assessment, irrigation management or disease control, amongst others (e.g., Boulard et al., 2002, 2004; Kichah et al., 2012). Future perspectives, discussed below, are therefore mainly oriented towards the use of CFD, which could alleviate some of the remaining knowledge gaps with respect to convective transfer, which were not (or could not yet be) dealt with experimentally.

Convective heat and mass transfer at leaf surfaces is inherently a coupled transfer problem, particularly due to the discretelydistributed stomata. Artificial leaves do not allow to mimic these conditions, as with real leaves. With the latter however, the stomatal opening shows a complex dependency of several influence factors, and is not straightforward to monitor real-time. CFD allows to resolve such coupled transfer down to the microscale (i.e., stomatal level) with good control of all parameters, such as stomatal opening. This could provide more insight on the transient transfer phenomena at the microscale, which is not straightforward with experimental techniques. A microscale CFD study was performed by Defraeye et al. (2012a) for spherical horticultural products to investigate the influence of discretely-distributed sources (lenticels, cracks or droplets) on the convective scalar transfer rate. They showed that even at rather low surface coverage ratios, relatively large convective flow rates were present, which were a function of coverage ratio, Reynolds number and source size (Figure 4).

CFD has been applied to study convective transfer phenomena at different spatial scales, i.e., from canopy level down to stomatal level (section 3.3). At the smallest scales (leaf and sub-leaf level), research efforts were however limited, as the porous medium approach could be used to circumvent modelling at these scales. Although CFD can/has been applied at multiple scales, a multiscale approach will be required in the future to combine/integrate transfer all scales, as resolving these 
Defraeye T., Verboven P., Ho Q.T., Nicolai B., Convective heat and mass exchange predictions at leaf surfaces: applications, methods and perspectives, Computers and Electronics in Agriculture 96, 180-201. http://dx.doi.org/10.1016/j.compag.2013.05.008

scales simultaneously is computationally not feasible. Similar to laboratory experiments, as mentioned above, the main challenge lies thus in accurately transferring the results at small scales (stomatal or leaf level) to a canopy scale, and often also vice versa. Also note that multiple scales exist on a temporal level, which should be dealt with accordingly. The multiscale modeling paradigm has recently been successfully applied for gas exchange in fruits (Ho et al., 2011) and roots (Verboven et al., 2012). Multiscale modeling allows to combine the relative simplicity of continuum-type models defined at macroscale level (canopy, tree, plant) with the level of detail of models incorporating the microscale features (leaf, stomata). In practice this could imply, for example, that a porous medium model for a plant/tree canopy can be improved by making leaf transpiration a function of the stomatal density and opening of the plant species, as obtained from microscale simulations at single leaf level.

For such numerical modelling, geometrical models of leaf surfaces and of the leaf's internal structure (e.g., stomata) are required, which can be obtained experimentally or by computational modelling. Macroscale geometrical models, i.e., of an entire leaf, are rather straightforward to obtain experimentally. Both simplified models, based on impressions or pictures, as well as more realistic models, from 3D imaging (e.g., with laser scanning system), have been used. In addition, computational modelling, including leaf development and venation patterns, is also successful in generating realistic (macroscale) leaf models (Prusinkiewicz and Runions, 2012). Obtaining 3D geometrical models at the leaf microscale is more challenging. When using imaging, a very high resolution is required. 2D imaging (e.g., atomic force microscopy, scanning electron microscopy) is less suitable as only the surface characteristics are obtained and construction of realistic $3 \mathrm{D}$ geometrical models from $2 \mathrm{D}$ images is not straightforward. 3D (micro-)imaging techniques (X-ray micro-computed tomography, magnetic resonance imaging, etc., see Falcone et al., 2006) are preferred for this purpose as they allow explicit imaging of the exterior (e.g., trichomes) and interior structure (e.g., organelles inside the cells) and 3D models can be directly reconstructed from the images. 3-D microstructures of plant organs have been analysed recently with such 3D imaging techniques (e.g., Kuroki et al., 2004; Mendoza et al., 2007; Verboven et al., 2008; Kaiser, 2009; Dhondt et al., 2010; Verboven et al., 2012). Computational modelling at the microscale, e.g., of cellular patterns and their growth, has been performed mostly two-dimensional (Abera et al., 2012; Prusinkiewicz and Runions, 2012), although recent developments are focussing on generation of 3D models including multiple tissue types (e.g., cuticle, mesophyll cells, etc.).

Convective transfer at leaf surfaces is usually quantified by means of CTCs, determined from literature or own experiments. Such CTCs, and CTC- $U$ correlations, are mostly derived for simplified configurations, such as single leaves, and are very casespecific. Furthermore, spatial and temporal CTCs variation is often not accounted for. Also, CMTCs are often estimated from 
Defraeye T., Verboven P., Ho Q.T., Nicolai B., Convective heat and mass exchange predictions at leaf surfaces: applications, methods and perspectives, Computers and Electronics in Agriculture 96, 180-201. http://dx.doi.org/10.1016/j.compag.2013.05.008

CHTCs by using the heat and mass transfer analogy. Finally, CTCs are strongly dependent on the reference conditions $\left(T_{\text {ref }}\right.$ and $p_{v, r e f}$, Eq.(1) and (2)) and the location where these are evaluated. The use of CTCs can thus compromise the accuracy of the convective heat and mass transfer predictions (Defraeye et al., 2011; Defraeye et al., 2012b). An alternative to the use of such CTCs is directly modelling the air-side transfer for the specific case under study, with CFD, from which CTCs can be determined a-posteriori (Defraeye et al., 2012c). A trend towards case-specific convective transfer predictions is emerging, where flow and scalar transfer around the leaf and the plant are explicitly resolved without using CTCs.

Most research still focussed on forced convection, i.e., in wind tunnels, compared to natural/mixed convection (see section 3.2), since the former is less dependent on the boundary conditions, more repeatable, and results in more generally useable correlations. Windless conditions are however often more critical (and lethal) for plants, due to lower convective and evaporative cooling. In this case, the importance of convective transfer, and accurate predictions thereof, also increases, compared to the stomatal resistance, as CTCs are low. Research efforts should focus more on the natural convective regime. Although existing artificial leaves successfully allow to study this flow regime, numerical methods are also suitable for straightforward parameter/sensitivity studies.

Previous studies on real leaves or branches have only considered a single leaf sample or a limited number of leaves. Intraspecies variability will, however, lead to a certain variability on the CTCs, by which the actual average CTC of leaves in a plant/tree can be different. Future experimental or numerical studies could assess such variability by a stochastic analysis on a large population of leaves of the same species.

Finally, recent efforts are also concentrated towards modelling dynamic plant/tree motion due to mechanical interaction of plants and trees with flow (Gosselin and de Langre, 2009; Dupont et al., 2010; Rodriguez et al., 2012), which is called fluidstructure interaction modelling. When coupled to convective transfer as well, this would allow computational studies of the impact of leaf flutter on transpiration rate, for example.

\section{$\underline{\text { 5. Conclusions }}$}

This study dealt with convective heat and mass exchange of leaves with the environment, which is usually quantified by means of convective transfer coefficients (CTCs), often by correlations with the air speed. Such CTC predictions can be obtained by analytical, experimental or numerical methods, which predominantly use real, artificial but also virtual leaf sensors. A detailed 
Defraeye T., Verboven P., Ho Q.T., Nicolai B., Convective heat and mass exchange predictions at leaf surfaces: applications, methods and perspectives, Computers and Electronics in Agriculture 96, 180-201.

http://dx.doi.org/10.1016/j.compag.2013.05.008

overview on past research was given for each of these methods, and the restrictions of the current techniques were identified, as well as the resulting knowledge gaps.

Analytical and (semi-)empirical methods to estimate CTCs, based on flat plates, are clearly most straightforward to use as such estimates are well known and readily available. Compared to an actual leaf, such flat-plate configurations, however, lack physical similarity with respect to the geometry and the flow field. Furthermore, the boundary conditions which are usually applied here are not representative for real leaves. Particularly the stomata, via which transpiration predominantly occurs and where evaporation takes place, result in very heterogeneous heat and mass boundary conditions at microscale level, which are not accounted for by most analytical methods.

Experimental methods rely on two types of sensors to determine CTCs: real and artificial leaves. With real leaves, all relevant physics are included, but these sensors are less controllable and an intraspecies variability inherently exists, i.e., each leaf is different. With artificial leaves, repeatability and accuracy are generally improved, but again a mismatch in boundary conditions exists at microscale level, since stomata are not accounted for. These sensors are used for two types of experiments, namely in the field and in the laboratory. Field experiments provide realistic environmental conditions, but thereby also a large amount of influence factors are present, which are difficult to control. Often the obtained CTCs are very case specific, with low repeatability of the measurements. Laboratory experiments on the other hand show improved repeatability and accuracy, since more control is available, as well as a higher resolution. Nevertheless, the size of the setup is limited (e.g., wind tunnel), by which aerodynamic interference effects, present in canopies, were often not accounted for. Scaling of the test setup could however provide an outcome here.

Numerical methods to predict air-side convective transfer generally rely on computational fluid dynamics (CFD) simulations. Although such methods have been used frequently to assess flow at the canopy or plant/tree scale, their use at the leaf and subleaf scale is very limited, but shows large potential. Apart from issues related to modelling accuracy, CFD is capable of providing flow field and scalar transfer information at very high spatial and temporal resolution, where all relevant physics can, in principle, be included in the model. CFD seems thus appropriate for clarifying some of the remaining knowledge gaps on convective heat and mass transfer and its interaction with the leaf, such as tissue mechanics.

Therefore, future perspectives are mainly oriented towards the use of CFD as it is a powerful tool to model all aspects of coupled convective heat and mass transfer at multiple scales, with which parameter and sensitivity studies can be performed in 
Defraeye T., Verboven P., Ho Q.T., Nicolai B., Convective heat and mass exchange predictions at leaf surfaces: applications, methods and perspectives, Computers and Electronics in Agriculture 96, 180-201. http://dx.doi.org/10.1016/j.compag.2013.05.008

a straightforward way. Challenges however exist in modelling all these scales, which is not feasible simultaneously due to computational restrictions, and which thus will require a multiscale modelling approach. Finally, generally applicable CTCs or CTC correlations with the air speed are difficult to obtain for leaves, due to the complex and case-dependent flow field and environmental conditions. CFD, however, allows direct modelling of the air-side transfer, by which the use of CTCs can be avoided. A trend towards such case-specific convective transfer predictions is expected.

\section{$\underline{\text { Acknowledgements }}$}

Thijs Defraeye and Quang Tri Ho are postdoctoral fellows of the Research Foundation - Flanders (FWO) and acknowledge its support. Financial support by the Research Foundation - Flanders (project FWO G.0603.08), KU Leuven (project OT 08/023) and the agency for Innovation by Science and Technology IWT (project 080528) is also gratefully acknowledged. These sponsors had no involvement in: the study design, the collection, analysis and interpretation of data; the writing of the manuscript; and the decision to submit the manuscript for publication. 
Defraeye T., Verboven P., Ho Q.T., Nicolai B., Convective heat and mass exchange predictions at leaf surfaces: applications, methods and perspectives, Computers and Electronics in Agriculture 96, 180-201. http://dx.doi.org/10.1016/j.compag.2013.05.008

\section{References}

Abera, M., Fanta, S.W., Verboven, P., Ho, Q.T., Carmeliet, J., Nicolai, B., 2012. Virtual fruit tissue generation based on cell growth modelling. Food Bioprocess Technol., art.nr. 775 (doi:10.1007/s11947-011-0775-4).

Abdul Majeed, P.M., 1981. Analysis of heat transfer during hydrair cooling of spherical food products. Int. J. Heat Mass Tran. 24 (2), 323-333.

Allais, I., Alvarez, G., Flick, D., 2006. Modelling cooling kinetics of a stack of spheres during mist chilling. J. Food Eng. 72 (2), 197-209.

Ambaw, A., Delele, M., Defraeye, T., Ho, Q.T., Opara, U.L., Nicolai, B.M., Verboven, P., 2012. The use of CFD to characterize and design post-harvest storage facilities: Past, present and future. Comput. Electron. Agric., accepted (doi:10.1016/j.compag.2012.05.009).

Bailey, B.J., Meneses, J.F., 1995. Modelling leaf convective heat transfer. Acta Hortic. 399, 191-198.

Balding, F.R., Cunningham, G.L., 1976. A comparison of heat transfer characteristics of simple and pinnate leaf models, Bot. Gaz. 137, 65-74.

Barlow, J.F., Belcher, S.E., 2002. A wind tunnel model for quantifying fluxes in the urban boundary layer. Boundary-Layer Meteorol. 104 (1), 131-150.

Barlow, J.F., Harman, I.N., Belcher, S.E., 2004. Scalar fluxes from urban street canyons part 1: Laboratory simulation. Boundary-Layer Meteorol. 113 (3), 369-385.

Bartzanas, T., Kacira, M., Zhu, H., Karmakar, S., Tamimi, E., Katsoulas, N., Lee, I.B., Kittas, C., 2013. Computational fluid dynamics applications to improve crop production systems. Comput. Electron. Agric., In Press (DOI:10.1016/j.compag.2012.05.012).

Bauerle, W.L., Bowden, J.D., 2011. Predicting transpiration response to climate change: insights on physiological and morphological interactions that modulate water exchange from leaves to canopies. HortScience 46 (2), 163-166.

Belhamri, A., Fohr, J.P., 1996. Heat and mass transfer along a wetted porous plate in an airstream. AIChE J. 42 (7), 18331843.

Ben Nasrallah, S., Perre, P., 1988. Detailed study of a model of heat and mass transfer during convective drying of porous media. Int. J. Heat Mass Transfer 31 (5), 957-967.

Benz, B.W., Martin, C.E., 2006. Foliar trichomes, boundary layers, and gas exchange in 12 species of epiphytic Tillandsia (Bromeliaceae). J. Plant Physiol. 163 (6), 648-656.

Blocken, B., Stathopoulos, T., Carmeliet, J., 2007. CFD simulation of the atmospheric boundary layer: wall function problems. Atmos. Environ. 41 (2), 238-252. 
Defraeye T., Verboven P., Ho Q.T., Nicolai B., Convective heat and mass exchange predictions at leaf surfaces: applications, methods and perspectives, Computers and Electronics in Agriculture 96, 180-201. http://dx.doi.org/10.1016/j.compag.2013.05.008

Boehncke, A., Siebers, J., Nolting, H.-G., 1990. Investigations of the evaporation of selected pesticides from natural and model surfaces in field and laboratory. Chemosphere 21 (9), 1109-1124.

Boulard, T., Fatnassi, H., Roy, J.C., Lagier, J., Fargues, J., Smits, N., Rougier, M., Jeannequin, B., 2004. Effect of greenhouse ventilation on humidity of inside air and in leaf boundary-layer. Agric. For. Meteorol. 125 (3-4), 225-239.

Boulard, T., Mermier, M., Fargues, J., Smits, N., Rougier, M., Roy, J.C., 2002. Tomato leaf boundary layer climate: implications for microbiological whitefly control in greenhouses. Agric. For. Meteorol. 110 (3), 159-176.

Boulard T., Wang S., 2002. Experimental and numerical studies on the heterogeneity of crop transpiration in a plastic tunnel. Comput. Electron. Agric. 34 (1-3), 173-190.

Brenner, A.J., Jarvis, P.G., 1995. A heated leaf replica technique for determination of leaf boundary layer conductance in the field. Agric. For. Meteorol. 72 (3-4), 261-275.

Cannon, J.N., Krantz, W.B., Kreith, F., Naot, D., 1979. A study of transpiration from porous flat plates simulating plant leaves. Int. J. Heat Mass Transfer 22 (3), 469-483.

Cebeci, T., Bradshaw, P., 1984. Physical and Computational aspects of Convective Heat Transfer, first ed. Springer-Verlag, New York, USA.

Cermak, J., Jimenez, S.M., González-Rodríguez, A.M., Morales, D., 2002. Laurel forests in Tenerife, Canary Islands II. Efficiency of the water conducting system in Laurus azorica trees. Trees - Struct. Funct. 16, 538-546.

Chen, C., 2003. Development of a heat transfer model for plant tissue culture vessels. Biosystems Eng. 85 (1), 67-77.

Chen, J.-M., Ibbetson, A., Milford, J.R., 1988a. Boundary layer resistances of artificial leaves in turbulent air - 1. Leaves parallel to the mean flow. Boundary-Layer Meteorol. 45 (4), 371-390.

Chen, J.-M., Ibbetson, A., Milford, J.R., 1988b. Boundary layer resistances of artificial leaves in turbulent air - 2. Leaves inclined to the mean flow. Boundary-Layer Meteorol. 45 (4), 371-390.

Chilton, T.H., Colburn, A.P., 1934. Mass transfer (absorption) coefficients. Ind. Eng. Chem. 26 (11), 1183-1187.

Collatz, G.J., Ball, J.T., Grivet, C., Berry J.A., 1991. Physiological and environmental regulation of stomatal conductance, photosynthesis and transpiration: A model that includes a laminar boundary layer. Agric. For. Meteorol. 54 (2-4), 107-136.

Cowan, I.R., 1972. Mass and heat transfer in laminar boundary layers with particular reference to assimilation and transpiration in leaves. Agr. Meteorol. 10, 311-329.

Daudet, F.A., Silvestre, J., Ferreira, M.I., Valancogne, C., Pradelle, F., 1998. Leaf boundary layer conductance in a vineyard in Portugal. Agric. For. Meteorol. 89 (3-4), 255-267.

Daudet, F.A., Le Roux, X., Sinoquet, H., Adam, B., 1999. Wind speed and leaf boundary layer conductance variation within tree crown: Consequences on leaf-to-atmosphere coupling and tree functions. Agric. For. Meteorol. 97 (3), 171-185. 
Defraeye T., Verboven P., Ho Q.T., Nicolai B., Convective heat and mass exchange predictions at leaf surfaces: applications, methods and perspectives, Computers and Electronics in Agriculture 96, 180-201.

http://dx.doi.org/10.1016/j.compag.2013.05.008

Dauzat, J., Rapidel, B., Berger, A., 2001. Simulation of leaf transpiration and sap flow in virtual plants: model description and application to a coffee plantation in Costa Rica. Agric. For. Meteorol. 109 (2), 143-160.

Defraeye, T., Blocken, B., Carmeliet, J., 2010. CFD analysis of convective heat transfer at the surfaces of a cube immersed in a turbulent boundary layer. Int. J. Heat Mass Transfer 53 (1-3), 297-308.

Defraeye, T., Blocken, B., Carmeliet, J., 2011. Convective heat transfer coefficients for exterior building surfaces: Existing correlations and CFD modelling. Energy Convers. Manage. 52 (1), 512-522.

Defraeye, T., Herremans, E., Verboven, P., Carmeliet, J., Nicolai, B., 2012a. Convective heat and mass exchange at surfaces of horticultural products: a microscale CFD modelling approach. Agric. For. Meteorol. 162-163, 71-84.

Defraeye, T., Blocken, B., Derome, D., Nicolai, B., Carmeliet, J., 2012b. Convective heat and mass transfer modelling at airporous material interfaces: overview of existing methods and relevance. Chem. Eng. Sci. 74, 49-58.

Defraeye, T., Blocken, B., Carmeliet, J., 2012c. Analysis of convective heat and mass transfer coefficients for convective drying of a porous flat plate by conjugate modelling. Int. J. Heat Mass Transfer 55 (1-3), 112-124.

Dhondt, S., Vanhaeren, H., Van Loo, D., Cnudde, V., Inzé, D., 2010. Plant structure visualization by high-resolution X-ray computed tomography. Trends Plant Sci. 15 (8), 419-422.

Dixon, M., Grace, J., 1983. Natural convection from leaves at realistic Grashof numbers. Plant Cell Environ. 6 (8), 665-670.

Dixon, M., Grace, J., 1984. Effect of wind on the transpiration of young trees. Ann. Bot. 53 (6), 811-819.

Domingo, F., van Gardingen, P.R., Brenner, A.J., 1996. Leaf boundary layer conductance of two native species in southeast Spain. Agric. For. Meteorol. 81 (3-4), 179-199.

Dupont, S., Gosselin, F., Py, C., de Langre, E., Hémon, P., Brunet, Y., 2010. Modelling waving crops using large-eddy simulation: comparison with experiments and a linear stability analysis. J. Fluid Mech. 652, 5-44.

Dupont, S., Bonnefond, J.-M., Irvine, M., Lamaud, E., Brunet, Y., 2011. Long-distance edge effects in a pine forest with a deep and sparse trunk space: in situ and numerical experiments. Agric. For. Meteorol. 151 (3), 328-344.

Dupont, S., Irvine, M.R., Bonnefond, J.-M., Lamaud, E., Brunet, Y., 2012. Turbulent structures in a pine forest with a deep and sparse trunk space: stand and edge regions. Boundary-Layer Meteorol. 143 (2), 309-336.

Evans, J.R., Kaldenhoff, R., Genty, B., Terashima, I., 2009. Resistances along the $\mathrm{CO}_{2}$ diffusion pathway inside leaves. J. Exp. Bot. 60 (8), 2235-2248.

Falcone, P.M., Baiano, A., Conte, A., Mancini, L., Tromba, G., Zanini, F., Del Nobile, M.A., 2006. Imaging techniques for the study of food microstructure: A review. Adv. Food Nutr. Res. 51, 205-263. 
Defraeye T., Verboven P., Ho Q.T., Nicolai B., Convective heat and mass exchange predictions at leaf surfaces: applications, methods and perspectives, Computers and Electronics in Agriculture 96, 180-201. http://dx.doi.org/10.1016/j.compag.2013.05.008

Fargues, J., Smits, N., Rougier, M., Boulard, T., Ridray, G., Lagier, J., Jeannequin, B., Fatnassi, H., Mermier, M., 2005. Effect of microclimate heterogeneity and ventilation system on enthomopathogenic hyphomycetes infection of Trialeurodes vaporariorum (Homoptera: Aleyrodidae) in Mediterranean greenhouse tomato. Biol. Control 32, 461-472.

Franco, A., Valera, D.L., Peña, A., Pérez, A.M., 2011. Aerodynamic analysis and CFD simulation of several cellulose evaporative cooling pads used in Mediterranean greenhouses. Comput. Electron. Agric. 76 (2), 218-230.

Friend, A.D., 1995. PGEN: an integrated model of leaf photosynthesis, transpiration, and conductance. Ecol. Model. 77 (2-3), 233-255.

Gates, D.M., Benedict, C.M., 1963. Convection phenomena from plants in still air. Am. J. Bot. 50 (6), 563-573.

Gates, D.M., Tibbals, E.C., Kreith, F., 1965. Radiation and convection for ponderosa pine. Am. J. Bot. 52 (1), 66-71.

Glass, C.R., Walters, K.F., Gaskell, P.H., Lee, Y.C., Thompson, H.M., Emerson, D.R., Gu, X.J., 2010. Recent advances in computational fluid dynamics relevant to the modelling of pesticide flow on leaf surfaces. Pest Manag. Sci. 66 (1), 2-9.

Gottschlich, D.E., Smith, A.P., 1982. Convective heat transfer characteristics of toothed leaves. Oecologia 53 (3), $418-420$.

Grace, J., Fasehun, F.E., Dixon, M., 1980. Boundary layer conductance of the leaves of some tropical timber trees. Plant Cell Environ. 3 (6), 443-450.

Grace, J., Wilson, J., 1976. The boundary layer over a Populus leaf. J. Exp. Bot. 27 (2), 231-241.

Grantz, D.A., Vaughn, D.L., 1999. Vertical profiles of boundary layer conductance and wind speed in a cotton canopy measured with heated brass surrogate leaves. Agric. For. Meteorol. 97 (3), 187-197.

Green, S., 1992. Modelling turbulent air flow in a stand of widely-spaced trees. Phoenics J. Comp. Fluid Dyn. Appl. 2, 294312.

Gromke, C., Ruck B., 2007. Influence of trees on the dispersion of pollutants in an urban street canyon - Experimental investigation of the flow and concentration field. Atmos. Environ. 41 (16), 3287-3302.

Gromke, C., Riccardo, B., Di Sabatino, S., Ruck, B., 2008. Dispersion study in a street canyon with tree planting by means of wind tunnel and numerical investigations - Evaluation of CFD data with experimental data. Atmos. Environ. 42 (37), 86408650 .

Gromke, C., 2011. A vegetation modeling concept for Building and Environmental Aerodynamics wind tunnel tests and its application in pollutant dispersion studies. Environ. Pollut. 159 (8-9), 2094-2099.

Gosselin, F., de Langre, E., 2009. Destabilising effects of plant flexibility in air and aquatic vegetation canopy flows. Eur. J. Mech. B-Fluid. 28 (2), 271-282.Gurevitch, J., Schuepp, P.H., 1990. Boundary layer properties of highly dissected leaves: an investigation using an electrochemical fluid tunnel. Plant Cell Environ. 13 (8), 783-792. 
Defraeye T., Verboven P., Ho Q.T., Nicolai B., Convective heat and mass exchange predictions at leaf surfaces: applications, methods and perspectives, Computers and Electronics in Agriculture 96, 180-201. http://dx.doi.org/10.1016/j.compag.2013.05.008

Haseba, T., 1974. Mass transfer across the boundary layer on plant leaves I: Preliminary study of water-vapor transfer from a leaf-like flat plate with separated evaporation sources. J. Agric. Meteorol. 30 (2), 45-55.

Hiraoka, H., 2005. An investigation of the effect of environmental factors on the budgets of heat, water vapor, and carbon dioxide within a tree. Energy 30 (2-4), 281-298.

Ho, Q.T., Verboven, P., Verlinden, B.E., Herremans, E., Wevers, M., Carmeliet, J., Nicolai, B.M., 2011. A three-dimensional multiscale model for gas exchange in fruit. Plant Physiol. 155 (3), 1158-1168.

Hodges, D.M., Toivonen, P.M.A., 2008. Quality of fresh-cut fruits and vegetables as affected by exposure to abiotic stress. Postharvest Biol. Technol. 48 (2), 155-162.

Holbrook, N.M., Zwieniecki, M.A., 2005. Vascular Transport in Plants, first ed. Elsevier Academic Press, London, UK.

Holopainen, J.K., 2004. Multiple functions of inducible plant volatiles. Trends Plant Sci. 9 (11), 529-533.

Impron, I., Hemming, S., Bot, G.P.A., 2008. Effects of cover properties, ventilation rate, and crop leaf area on tropical greenhouse climate. Biosystems Eng. 99 (4), 553-564.

Iqbal, M., Stoffers, J.A., 1975. Natural convection heat transfer in covered plant canopies. Agr. Meteorol. 15 (1), $97-111$.

Iskra, C.R., James, C., Talukdar, P., Simonson, C.J., 2009. Convective mass transfer coefficients for gypsum and wood panelling. J. ASTM Int. 6 (4), 1-18 (JAI102036).

Jarvis, P.G., McNaughton, K.G., 1986. Stomatal control of transpiration: scaling up from leaf to region. Adv. Ecol. Res. 15, 149.

Jayalakshmy, M.S., Philip, J., 2010. Thermophysical properties of plant leaves and their influence on the environment temperature. Int. J. Thermophys. 31 (11-12), 2295-2304.

Jordan, D.N., Smith, W.K., 1994. Energy balance analysis of nighttime leaf temperatures and frost formation in a subalpine environment. Agric. For. Meteorol. 71 (3-4), 359-372.

Kaiser, H., 2009. The relation between stomatal aperture and gas exchange under consideration of pore geometry and diffusional resistance in the mesophyll. Plant Cell Environ. 32, 1091-1098.

Katsoulas, N., Baille, A., Kittas, C., 2001. Effect of misting on transpiration and conductances of a greenhouse rose canopy. Agric. For. Meteorol. 106 (3), 233-247.

Katsoulas, N., Baille, A., Kittas, C., 2007. Leaf boundary layer conductance in ventilated greenhouses: An experimental approach. Agric. For. Meteorol. 144 (3-4), 180-192.

Katul, G.G., Mahrt, L., Poggi, D., Sanz, C., 2004. One- and two-equation models for canopy turbulence. Boundary-Layer Meteorol. 113 (1), 81-109. 
Defraeye T., Verboven P., Ho Q.T., Nicolai B., Convective heat and mass exchange predictions at leaf surfaces: applications, methods and perspectives, Computers and Electronics in Agriculture 96, 180-201.

http://dx.doi.org/10.1016/j.compag.2013.05.008

Kaya, A., Aydin, O., 2009. An experimental study on drying kinetics of some herbal leaves. Energy Convers. Manage. 50 (1), $118-124$

Kays, W.M., Crawford, M.E., 1993. Convective Heat and Mass Transfer, third ed., McGraw-Hill, USA.

Kichah, A., Bournet, P.-E., Migeon, C., Boulard, T., 2012. Measurement and CFD simulation of microclimate characteristics and transpiration of an Impatiens pot plant crop in a greenhouse. Biosystems Eng. 112 (1), 22-34.Kim, H.K., Lee, S.J., 2010. Synchrotron X-ray imaging for nondestructive monitoring of sap flow dynamics through xylem vessel elements in rice leaves. New Phytol. 188 (4), 1085-1098.

Kitano, M., Eguchi, H., 1987a. Air humidity within boundary layer of a transpiring leaf - I. Relationship between transpiration and water vapor density at leaf surface. Biotronics 16, 39-45.

Kitano, M., Eguchi, H., 1987b. Air humidity within boundary layer of a transpiring leaf - II. Profile of water vapor density within the boundary layer. Biotronics 16, 47-55.

Kitano, M., Eguchi, H., 1989. Dynamic analysis of stomatal responses by an improved method of leaf heat balance. Environ. Exp. Bot. 29 (2), 175-185.

Kitano, M., Eguchi, H., 1990. Buoyancy effect on forced convection in the leaf boundary layer. Plant Cell Environ. 3 (9), $965-$ 970.

Kitano, M., Tateishi, J., Eguchi, H., 1995. Evaluation of leaf boundary layer conductance of a whole plant by application of abscisic acid inhibiting transpiration. Biotronics 24, 51-58.

Kittas, C., Katsoulas, N., Baille, A., 2001. Influence of greenhouse ventilation regime on the microclimate and energy partitioning of a rose canopy during summer conditions. J. Agric. Eng. Res. 79 (3), 349-360.

Knoerr, K.R., Gay, L.W., 1965. Tree leaf energy balance. Ecology 46 (1-2), 17-24.

Kondjoyan, A., 2006. A review on surface heat and mass transfer coefficients during air chilling and storage of food products. Int. J. Refrig. 29 (6), 863-875.

Köse, B., Erentürk, S., 2010. Drying characteristics of mistletoe (Viscum album L.) in convective and UV combined convective type dryers. Ind. Crops Prod. 32 (3), 394-399.

Kosugi, Y., Takanashi, S., Matsuo, N., Tanaka, K., Tanaka, H., 2006. Impact of leaf physiology on gas exchange in a Japanese evergreen broad-leaved forest. Agric. For. Meteorol. 139 (3-4), 182-199.

Kumar, A., Barthakur, N., 1971. Convective heat transfer measurements of plants in a wind tunnel. Boundary-Layer Meteorol. $2(2), 218-227$.

Kuroki, S., Oshita, S., Sotome, I., Kawagoe, Y., Seo, Y., 2004. Visualization of 3-D network of gas-filled intercellular spaces in cucumber fruit after harvest. Postharvest Biol. Technol. 33 (3), 255-262. 
Defraeye T., Verboven P., Ho Q.T., Nicolai B., Convective heat and mass exchange predictions at leaf surfaces: applications, methods and perspectives, Computers and Electronics in Agriculture 96, 180-201. http://dx.doi.org/10.1016/j.compag.2013.05.008

Lambers, H., Chapin, F.S., Pons, T.L., 2008. Plant Physiological Ecology, second ed., Springer Science + Business Media, New York, USA.

Lamorlette, A., Collin, A., 2012. Analytical quantification of convective heat transfer inside vegetal structures. Int. J. Therm. Sci. 57, 78-84.Landsberg, J.J., Ludlow, M.M., 1970. A technique for determining resistance to mass transfer through the boundary layers of plants with complex structure. J. Appl. Ecol. 7 (1), 187-192.

Landsberg, J.J., Powell, D.B.B., 1973. Surface exchange characteristics of leaves subject to mutual interference. Agr. Meteorol. 12, 169-184.

Leigh, A., Close, J.D., Ball, M.C., Siebke, K., Nicotra, A.B., 2006. Leaf cooling curves: measuring leaf temperature in sunlight. Funct. Plant Biol. 33 (5), 515-519.

Lerdau, M., Guenther, A., Monson, R., 1997. Plant production and emission of volatile organic compounds. BioScience 47 (6), 373-383.

Leuning, R., Cremer, K.W., 1988. Leaf temperatures during radiation frost - Part I. Observations. Agric. For. Meteorol. 42 (23), 121-133.

Leuning, R., Foster, I.J., 1990. Estimation of transpiration by single trees: comparison of a ventilated chamber, leaf energy budgets and a combination equation. Agric. For. Meteorol. 51 (1), 63-86.

Lienhard IV, J.H., Lienhard V, J.H., 2006. A Heat Transfer Textbook, third ed. Phlogiston Press, Cambridge Massachusetts, USA.

Linacre, E.T., 1967. Further studies of the heat transfer from a leaf. Plant Physiol. 42 (5), 651-658.

Ludlow, M.M., Björkman, O., 1984. Paraheliotropic leaf movement in Siratro as a protective mechanism against droughtinduced damage to primary photosynthetic reactions: damage by excessive light and heat. Planta 161 (6), 505-518.

Majdoubi, H., Boulard, T., Fatnassi, H., Bouirden, L., 2009. Airflow and microclimate patterns in a one-hectare Canary type greenhouse: An experimental and CFD assisted study. Agric. For. Meteorol. 149 (6-7), 1050-1062.

Mansfield, T.A., 1998. Stomata and plant water relations: does air pollution create problems?. Environ. Pollut. 101 (1), 1-11.

Marenco, R.A., Siebke, K., Farquhar, G.D., Ball, M.C., 2006. Hydraulically based stomatal oscillations and stomatal patchiness in Gossypium hirsutum. Funct. Plant Biol. 33 (12), 1103-1113.

Maricle, B.R., Cobos, D.R., Campbell, C.S., 2007. Biophysical and morphological leaf adaptations to drought and salinity in salt marsh grasses. Environ. Exp. Bot. 60 (3), 458-467.

Martin, T.A., Hinckley, T.M., Meinzer, F.C., Sprugel, D.G., 1999. Boundary layer conductance, leaf temperature and transpiration of Abies amabilis branches. Tree Physiol. 19 (7), 435-443. 
Defraeye T., Verboven P., Ho Q.T., Nicolai B., Convective heat and mass exchange predictions at leaf surfaces: applications, methods and perspectives, Computers and Electronics in Agriculture 96, 180-201. http://dx.doi.org/10.1016/j.compag.2013.05.008

Meinzer, F., Goldstein, G., 1985. Some consequences of leaf pubescence in the Andean giant rosette plant Espeletia timotensis. Ecology 66 (2), 512-520.

Meinzer, F.C., Goldstein, G., Holbrook, N.M., Jackson, P., Cavelier, J., 1993. Stomatal and environmental control of transpiration in a lowland tropical forest tree. Plant Cell Environ. 16 (4), 429-436.

Melese Endalew, A., Hertog, M., Baetens, K., Delele, M., Persoons, T., Baelmans, M., Ramon, H., Nicolai, B., Verboven, P., 2009. CFD modelling and wind tunnel validation of airflow through plant canopies using 3D canopy architecture. Int. J. Heat Fluid Flow 30 (2), 356-368.

Melese Endalew, A., Debaer, C., Rutten, N., Vercammen, J., Delele, M., Ramon, H., Nicolai, B., Verboven, P., 2010a. Modelling pesticide flow and deposition from air-assisted orchard spraying in orchards: A new integrated CFD approach. Agric. For. Meteorol. 150 (10), 1383-1392.

Melese Endalew, A., Debaer, C., Rutten, N., Vercammen, J., Delele, M., Ramon, H., Nicolai, B., Verboven, P., 2010b. A new integrated CFD modelling approach towards air-assisted orchard spraying. Part I. Model development and effect of wind speed and direction on sprayer airflow. Comput. Electron. Agric. 71 (2), 128-136.

Melese Endalew, A., Debaer, C., Rutten, N., Vercammen, J., Delele, M., Ramon, H., Nicolai, B., Verboven, P., 2010c. A new integrated CFD modelling approach towards air-assisted orchard spraying. Part II: Validation for different sprayer types. Comput. Electron. Agric. 71 (2), 137-147.

Melese Endalew, A., Debaer, C., Rutten, N., Vercammen, J., Delele, M., Ramon, H., Nicolai, B., Verboven, P., 2011. Modelling the effect of tree foliage on sprayer airflow in orchards. Boundary-Layer Meteorol. 138 (1), 139-162.

Mendoza, F., Verboven, P., Mebatsion, H.K., Kerckhofs, G., Wevers, M., Nicolai, B.M., 2007. Three-dimensional pore space quantification of apple tissue using X-ray computed microtomography. Planta 226 (3), 559-570.

Michaletz, S.T., Johnson, E.A., 2006. Foliage influences forced convection heat transfer in conifer branches and buds. New Phytol. 170 (1), 87-98.

Mishio, M., Kawakubo, N., Kachi, N., 2007. Intraspecific variation in leaf morphology and photosynthetic traits in Boninia grisea Planchon (Rutaceae) endemic to the Bonin Islands, Japan. Plant Species Biol. 22 (2), 117-124.

Mistriotis, A., Arcidiacono, C., Picuno, P., Bot, G.P.A., Scarascia-Mugnozza, G., 1997. Computational analysis of ventilation in greenhouses at zero- and low-wind speeds. Agric. For. Meteorol. 88 (1-4), 121-135.

Mochida, A., Tabata, Y., Iwata, T., Yoshino, H., 2008. Examining tree canopy models for CFD prediction of wind environment at pedestrian level. J. Wind Eng. Ind. Aerodyn. 96 (10-11), 1667-1677.

Molina-Aiz, F.D., Fatnassi, H., Boulard, T., Roy, J.C., Valera, D.L., 2010. Comparison of finite element and finite volume methods for simulation of natural ventilation in greenhouses. Comput. Electron. Agric. 72 (2), 69-86. 
Defraeye T., Verboven P., Ho Q.T., Nicolai B., Convective heat and mass exchange predictions at leaf surfaces: applications, methods and perspectives, Computers and Electronics in Agriculture 96, 180-201. http://dx.doi.org/10.1016/j.compag.2013.05.008

Molina-Aiz, F.D., Valera, D.L., Alvarez, A.J., Madueno, A., 2006. A wind tunnel study of airflow through horticultural crops: determination of the drag coefficient. Biosystems Eng. 93 (4), 447-457.

Monteith, J.L., 1995. Accommodation between transpiring vegetation and the convective boundary layer. J. Hydrol. 166 (3-4), $251-263$

Morrison, J.E., Barfield, B.J., 1981. Transpiring artificial leaves. Agr. Meteorol. 24, 227-236.

Mott, K.A., Buckley, T.N., 2000. Patchy stomatal conductance - emergent collective behaviour of stomata. Trends Plant Sci. 5 (6), 258-262.

Murphy, C.E., Knoerr, K.R., 1977. Simultaneous determination of the sensible and latent heat transfer coefficients for tree leaves. Boundary-Layer Meteorol. 11, 223-241.

Musselman, R.C., 1988. Acid neutralizing capacity of leaves exposed to acidic fog. Environ. Exp. Bot. 28 (1), 27-32.

Neal, S.B.H.C., 1975. The development of the thin-film naphthalene mass-transfer analogue technique for the direct measurement of heat-transfer coefficients. Int. J. Heat Mass Transfer 18 (4), 559-567.

Nobel, P.S., 2005. Physicochemical and Environmental Plant Physiology, third ed., Elsevier Academic Press, London, UK.

Norton, T., Sun, D.-W., 2006. Computational fluid dynamics (CFD) - an effective and efficient design and analysis tool for the food industry: A review. Trends Food Sci. Techn. 17 (11), 600-620.

Parkhurst, D.F., 1976. Effects of Verbascum Thapsus leaf hairs on heat and mass transfer. New Phytol. 76 (3), 453-457.

Parkhurst, D.F., Duncan, P.R., Gates, D.M., Kreith, F., 1968. Wind-tunnel modelling of convection of heat between air and broad leaves of plants. Agr. Meteorol. 5 (1), 33-47.

Parkhurst, D.F., Pearman, G.I., 1974. Convective heat transfer from a semi-infinite flat plate to periodic flow at various angles of incidence. Agr. Meteorol. 13 (3), 383-393.

Parlange, J.-Y., Waggoner, P.E., 1972. Boundary layer resistance and temperature distribution on still and flapping leaves. II. Field experiments. Plant Physiol. 50 (1), 60-63.

Parlange, J.-Y., Waggoner, P.E., Heichel, G.H., 1971. Boundary layer resistance and temperature distribution on still and flapping leaves. I. Theory and laboratory experiments. Plant Physiol. 48 (4), 437-442.

Pearman, G.I., 1965. Preliminary studies of the loss of heat from leaves under conditions of free and forced convection. Australian J. Bot. 13 (2), 153-160.

Pearman, G.I., Weaver, H.L., Tanner, C.B., 1972. Boundary layer heat transfer coefficients under field conditions. Agr. Meteorol. 10, 83-92.

Pedersen, O., Colmer, T.D., 2012. Physical gills prevent drowning of many wetland insects, spiders and plants. J. Exp. Biol. 215 (5), 705-709. 
Defraeye T., Verboven P., Ho Q.T., Nicolai B., Convective heat and mass exchange predictions at leaf surfaces: applications, methods and perspectives, Computers and Electronics in Agriculture 96, 180-201. http://dx.doi.org/10.1016/j.compag.2013.05.008

Picotte, J.J., Rosenthal, D.M., Rhode, J.M., Cruzan, M.B., 2007. Plastic responses to temporal variation in moisture availability: consequences for water use efficiency and plant performance. Oecologia 153 (4), 821-832.

Prusinkiewicz, P., Runions, A., 2012. Computational models of plant development and form. New Phytol. 193 (3), 549-569.

Raschke, K., 1960. Heat transfer between the plant and the environment. Annu. Rev. Plant Physiol. 11, 111-126.

Reich, A., Holbrook, N.M., Ewel, J.J., 2004. Developmental and physiological correlates of leaf size in Hyeronima alchorneoides (Euphorbiaceae). Am. J. Bot. 91 (4), 582-589.

Renard, C., Demessemacker, W., 1983. Effects of wind velocity on stomatal conductance and consequences of leaf rolling on water uptake in tall fescue. Biol. Plantarum 25 (6), 408-411.

Rijsberman, F.R., 2006. Water scarcity: Fact or fiction?. Agric. Water Manage. 80 (1-3), 5-22.

Roberts, J., Cabral, O.M.R., De Aguiar, L.R., 1990. Stomatal and boundary-layer conductances in an Amazonian terra firme rain forest. J. Appl. Ecol. 27 (1), 336-353.

Roden, J.S., Pearcy, R.W., 1993. The effect of leaf flutter on the flux of $\mathrm{CO}_{2}$ in poplar leaves. Funct. Ecol. 7 (6), 669-675.

Rodriguez, M, Ploquin, S, Moulia, B, de Langre, E, 2012. The multimodal dynamics of a walnut tree: experiments and models. J. Appl. Mech. 79 (4), 044505.Roth-Nebelsick, A., 2001. Computer-based analysis of steady-state and transient heat transfer of small-sized leaves by free and mixed convection. Plant Cell Environ. 24 (6), 631-640.

Roth-Nebelsick, A., Hassiotou, F., Veneklaas, E.J., 2009. Stomatal crypts have small effects on transpiration: a numerical model analysis. Plant Physiol. 151, 2018-2027.

Roy, J.C., Vidal, C., Fargues, J., Boulard, T., 2008. CFD based determination of temperature and humidity at leaf surface. Comput. Electron. Agric. 61 (2), 201-212.

Saldin, T.F., Barthakur, N., 1971. Heat transfer between Phaseolus vulgaris and the environment. Can. J. Bot. 49 (6), 833-838.

Sanz, C., 2003. A note on k- $\varepsilon$ modelling of vegetation canopy air-flow. Boundary-Layer Meteorol. 108, 191-197.

Sase, S., Kacira, M., Boulard, T., Okushima, L., 2012. Wind tunnel measurement of aerodynamic properties of a tomato canopy. Trans. ASABE 55(5), 1921-1927.

Schlünder, E.U., 1988. On the mechanism of the constant drying rate period and its relevance to diffusion controlled catalytic gas phase reactions. Chem. Eng. Sci. 43 (10), 2685-2688.

Schreuder, M.D., Brewer, C.A., Heine, C., 2001. Modelled influences of non-exchanging trichomes on leaf boundary layers and gas exchange. J. Theor. Biol. 210 (1), 23-32.

Schuepp, P.H., 1972. Studies of forced-convection heat and mass transfer of fluttering realistic leaf models. Boundary-Layer Meteorol. 2 (3), 263-274. 
Defraeye T., Verboven P., Ho Q.T., Nicolai B., Convective heat and mass exchange predictions at leaf surfaces: applications, methods and perspectives, Computers and Electronics in Agriculture 96, 180-201. http://dx.doi.org/10.1016/j.compag.2013.05.008

Schuepp, P.H., 1973. Model experiments on free-convection heat and mass transfer of leaves and plant elements. BoundaryLayer Meteorol. 3 (4), 454-467.

Schuepp, P.H., 1980. Heat and moisture transfer from flat surfaces in intermittent flow: A laboratory study. Agr. Meteorol. 22 (3-4), 351-366.

Schuepp, P.H., 1982. Laboratory studies on dry deposition of submicron-size particles on coniferous foliage. Boundary-Layer Meteorol. 24 (4), 465-480.

Schuepp, P.H., 1993. Tansley Review No. 59: Leaf boundary layers. New Phytol. 125 (3), 477-507.

Shahba, M.A., Bauerle, W.L., 2009. Growth temperature modulates the spatial variability of leaf morphology and chemical elements within crowns of climatically divergent Acer rubrum genotypes. Tree Physiol. 29 (7), 869-877.

Shibuya, T., Tsuruyama, J., Kitaya, Y., Kiyota, M., 2006. Enhancement of photosynthesis and growth of tomato seedlings by forced ventilation within the canopy. Sci. Hortic. 109 (3), 218-222.

Shive, J.B., Brown, K.W., 1978. Quaking and gas exchange in leaves of cottonwood (Populus deltoides Marsh). Plant Physiol. $61(3), 331-333$.

Siegel, R., Sparrow, E.M., 1960. Comparison of turbulent heat-transfer results for uniform wall heat flux and uniform wall temperature. Trans. ASME: J. Heat Trans. 82, 152-153.

Silva, A.M., Rosa, R., Candeias, M., 1988. Heat and water vapor transfer across the boundary layer of artificial leaves in a greenhouse. Acta Hortic. 229, 399-404.

Silvani, X., Morandini, F., 2009. Fire spread experiments in the field: Temperature and heat fluxes measurements. Fire Safety J. 44 (2), 279-285.Sinclair, R., 1970. Convective heat transfer from narrow leaves. Aust. J. Biol. Sci. 23 (2), 309-322.

Smith, D.M., Jarvis, P.G., 1998. Physiological and environmental control of transpiration by trees in windbreaks. Forest Ecol. Manag. 105 (1-3), 159-173.

Smith, D.M., Jarvis, P.G., Odongo, J.C.W., 1997a. Energy budgets of windbreak canopies in the Sahel. Agric. For. Meteorol. $86(1-2), 33-49$.

Smith, D.M., Jarvis, P.G., Odongo, J.C.W., 1997b. Aerodynamic conductances of trees in windbreaks. Agric. For. Meteorol. $86(1), 17-31$.

Stokes, V.J., Morecroft, M.D., Morison, J.I.L., 2006. Boundary layer conductance for contrasting leaf shapes in a deciduous broadleaved forest canopy. Agric. For. Meteorol. 139 (1-2), 40-54.

Sun, D.-W., Zheng, L., 2006. Vacuum cooling technology for the agri-food industry: Past, present and future. J. Food Eng. 77 (2), 203-214. 
Defraeye T., Verboven P., Ho Q.T., Nicolai B., Convective heat and mass exchange predictions at leaf surfaces: applications, methods and perspectives, Computers and Electronics in Agriculture 96, 180-201.

http://dx.doi.org/10.1016/j.compag.2013.05.008

Tanaka, K., 2002. Multi-layer model of $\mathrm{CO}_{2}$ exchange in a plant community coupled with the water budget of leaf surfaces. Ecol. Modell. 147 (1), 85-104.

Tanaka, K., Kosugi, Y., Nakamura, A., 2002. Impact of leaf physiological characteristics on seasonal variation in $\mathrm{CO}_{2}$, latent and sensible heat exchanges over a tree plantation. Agric. For. Meteorol. 114 (1-2), 103-122.

Taylor, R.P., Coleman, H.W., Hosni, M.H., Love, P.H., 1989. Thermal boundary condition effects on heat transfer in the turbulent incompressible flat plate boundary layer. Int. J. Heat Mass Transfer 32 (6), 1165-1174.

Teklehaimanot, Z., Jarvis, P.G., 1991. Direct measurement of evaporation of intercepted water from forest canopies. J. Appl. Ecol. 28 (2), 603-618.

Tholen, D., Zhu, X.G., 2011. The mechanistic basis of internal conductance: a theoretical analysis of mesophyll cell photosynthesis and $\mathrm{CO}_{2}$ diffusion. Plant Physiol. 156 (1), 90-105.

Thom, A.S., 1968. The exchange of momentum, mass and heat between an artificial leaf and the airflow in a wind-tunnel. Q. J. R. Meteorolog. Soc. 94 (399), 44-55.

Thorpe, M.R., Butler, D.R., 1977. Heat transfer coefficients for leaves on orchard apple trees. Boundary-Layer Meteorol. 12 (1), 61-73.

Tibbals, E.C., Carr, E.K., Gates, D.M., Kreith, F., 1964. Radiation and convection in conifers. Am. J. Bot. 51 (5), $529-538$.

Unsworth, M.H., Wilshaw, J.C., 1989. Wet, occult and dry deposition of pollutants on forests. Agric. For. Meteorol. 47 (2-4), 221-238.

Verboven, P., Flick, D., Nicolai, B.M., Alvarez, G., 2006. Modelling transport phenomena in refrigerated food bulks, packages and stacks: basics and advances. Int. J. Refrig. 29 (6), 985-997.

Verboven, P., Kerckhofs, G., Mebatsion, H.K., Ho, Q.T., Temst, K., Wevers, M., Cloetens, P., Nicolai, B.M., 2008. 3-D gas exchange pathways in pome fruit characterised by synchrotron X-ray computed tomography. Plant Physiol. 147 (2), 518 527.

Verboven, P., Pedersen, O., Herremans, E., Ho, Q.T., Nicolai, B.M., Colmer, T.D., Teakle, N., 2012. Root aeration via aerenchymatous phellem: three dimensional micro-imaging and radial $\mathrm{O}_{2}$ profiles in Melilotus siculus. New Phytol. 193 (2), 420-431.

Vermeulen, K., Aerts, J.M., Dekock, J., Bleyaert, P., Berckmans, D., Steppe, K., 2012. Automated leaf temperature monitoring of glasshouse tomato plants by using a leaf energy balance model, Comput. Electron. Agric. 87, 19-31.

Vidal, C., Fargues, J., Rougier, M., Smits, N., 2003. Effect of air humidity on the infection potential of Hyphomycetous fungi as mycoinsecticides for Trialeurodes vaporariorum. Biocontrol Sci. Technol. 13 (2), 183-198.

Vogel, S., 1970. Convective cooling at low airspeeds and the shapes of broad leaves. J. Exp. Bot. 21 (1), 91-101. 
Defraeye T., Verboven P., Ho Q.T., Nicolai B., Convective heat and mass exchange predictions at leaf surfaces: applications, methods and perspectives, Computers and Electronics in Agriculture 96, 180-201. http://dx.doi.org/10.1016/j.compag.2013.05.008

Vogel, S., 2009. Leaves in the lowest and highest winds - temperature, force and shape. New Phytol. 183 (1), $13-26$.

Wigley, G., Clark, J.A., 1974. Heat transport coefficients for constant energy flux models of broad leaves. Boundary-Layer Meteorol. 7, 139-150.

Wuenscher, J.E., 1970. The effect of leaf hairs of Verbascum Thapsus on leaf energy exchange. New Phytol. 69, 65-73.

Xu, L., Zhu, H., Ozkan, H.E., Thistle, H.W., 2010. Evaporation rate and development of wetted area of water droplets with and without surfactant at different locations on waxy leaf surfaces. Biosystems Eng. 106 (1), 58-67.

Yu, Y., Zhu, H., Frantz, J.M., Reding, M.E., Chan, K.C., Ozkan, H.E., 2009a. Evaporation and coverage area of pesticide droplets on hairy and waxy leaves. Biosystems Eng. 104 (3), 324-334.

Yu, Y., Zhu, H., Ozkan, H.E., Derksen, R.C., Krause, C.R., 2009b. Evaporation and deposition coverage area of droplets containing insecticides and spray additives on hydrophilic, hydrophobic and crabapple leaf surfaces. Trans. ASABE 52 (1), $39-49$.

Zakharenkova, T.S., Averyanov, A.A., Pasechnik, T.D., Lapikova, V.P., Baker, C.J., 2012. Surface contact of cucumber or rice leaves with water can suppress their fungal diseases. Physiol. Mol. Plant Pathol. 79, 13-20. 
Defraeye T., Verboven P., Ho Q.T., Nicolai B., Convective heat and mass exchange predictions at leaf surfaces: applications, methods and perspectives, Computers and Electronics in Agriculture 96, 180-201.

http://dx.doi.org/10.1016/j.compag.2013.05.008

\section{Figures}

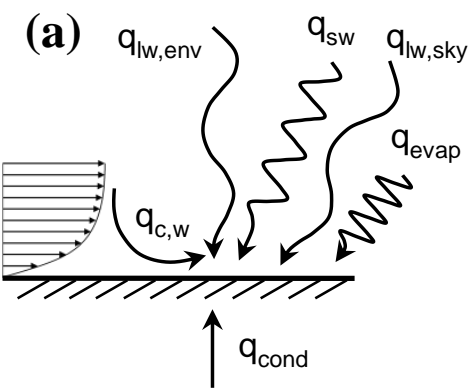

(b)

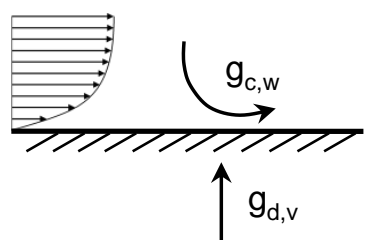

Figure 1. (a) Heat fluxes at leaf surface: net long-wave radiation exchange with the environment $\left(q_{l w, e n v}\right)$, i.e., with terrain and obstacles; (2) net long-wave radiation exchange with the sky $\left(q_{l w, s k y}\right)$; (3) short-wave solar radiation $\left(q_{s w, s k y}\right)$, including direct, reflected and diffuse radiation; (4) convective heat flux due to air movement along the leaf surface $\left(q_{c, w}\right)$; (5) conductive heat flux from the interior $\left(q_{\text {cond }}\right)$ of the leaf; (6) evaporative heat flux due to latent heat of evaporation $\left(q_{\text {evap }}\right)$. (b) Moisture fluxes at leaf surface: (1) diffusive flux of water vapour $\left(g_{d, v}\right)$ from the inside of the leaf, mainly via the stomata; (2) convective water vapour flux from the surface to the environment or vice versa $\left(g_{c, w}\right)$ as a result from air movement along the leaf surface. 
Defraeye T., Verboven P., Ho Q.T., Nicolai B., Convective heat and mass exchange predictions at leaf surfaces: applications, methods and perspectives, Computers and Electronics in Agriculture 96, 180-201.

http://dx.doi.org/10.1016/j.compag.2013.05.008

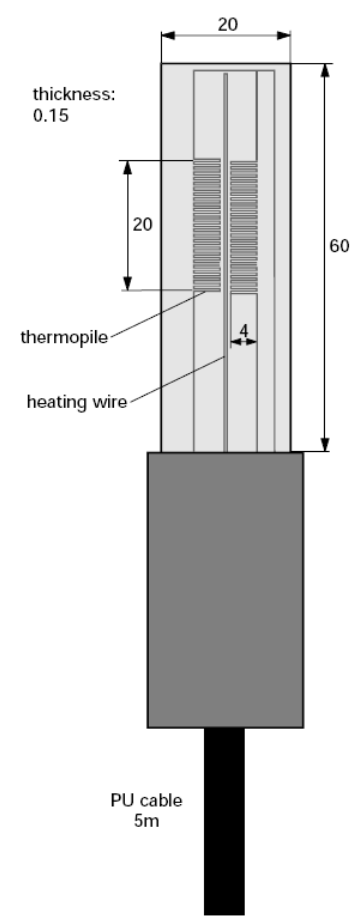

Figure 2. Example of boundary layer conductance sensor (schematic taken from Hukseflux Thermal Sensors, Manorville, USA, www.hukseflux.com). Dimensions are in mm. 
Defraeye T., Verboven P., Ho Q.T., Nicolai B., Convective heat and mass exchange predictions at leaf surfaces: applications, methods and perspectives, Computers and Electronics in Agriculture 96, 180-201.

http://dx.doi.org/10.1016/j.compag.2013.05.008

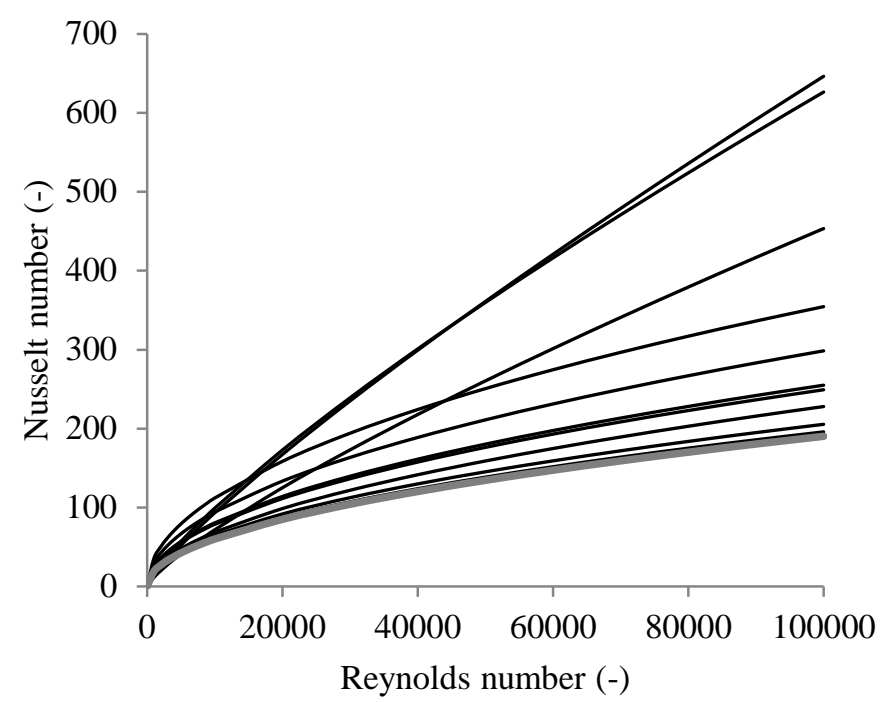

Figure 3. Correlations of Nusselt number $\left(N u_{D}\right.$ or $\left.N u_{B}\right)$ with Reynolds number of laboratory experiments presented in Table 3 (of Chen et al., 1988a, 1988b; Murphy and Knoerr, 1977; Sinclair, 1970; Smith et al., 1997b; Wigley and Clark, 1974). The correlation for laminar flow over a flat plate (from Lienhard and Lienhard, 2006) is indicated with a grey line. 
Defraeye T., Verboven P., Ho Q.T., Nicolai B., Convective heat and mass exchange predictions at leaf surfaces: applications, methods and perspectives, Computers and Electronics in Agriculture 96, 180-201.

http://dx.doi.org/10.1016/j.compag.2013.05.008
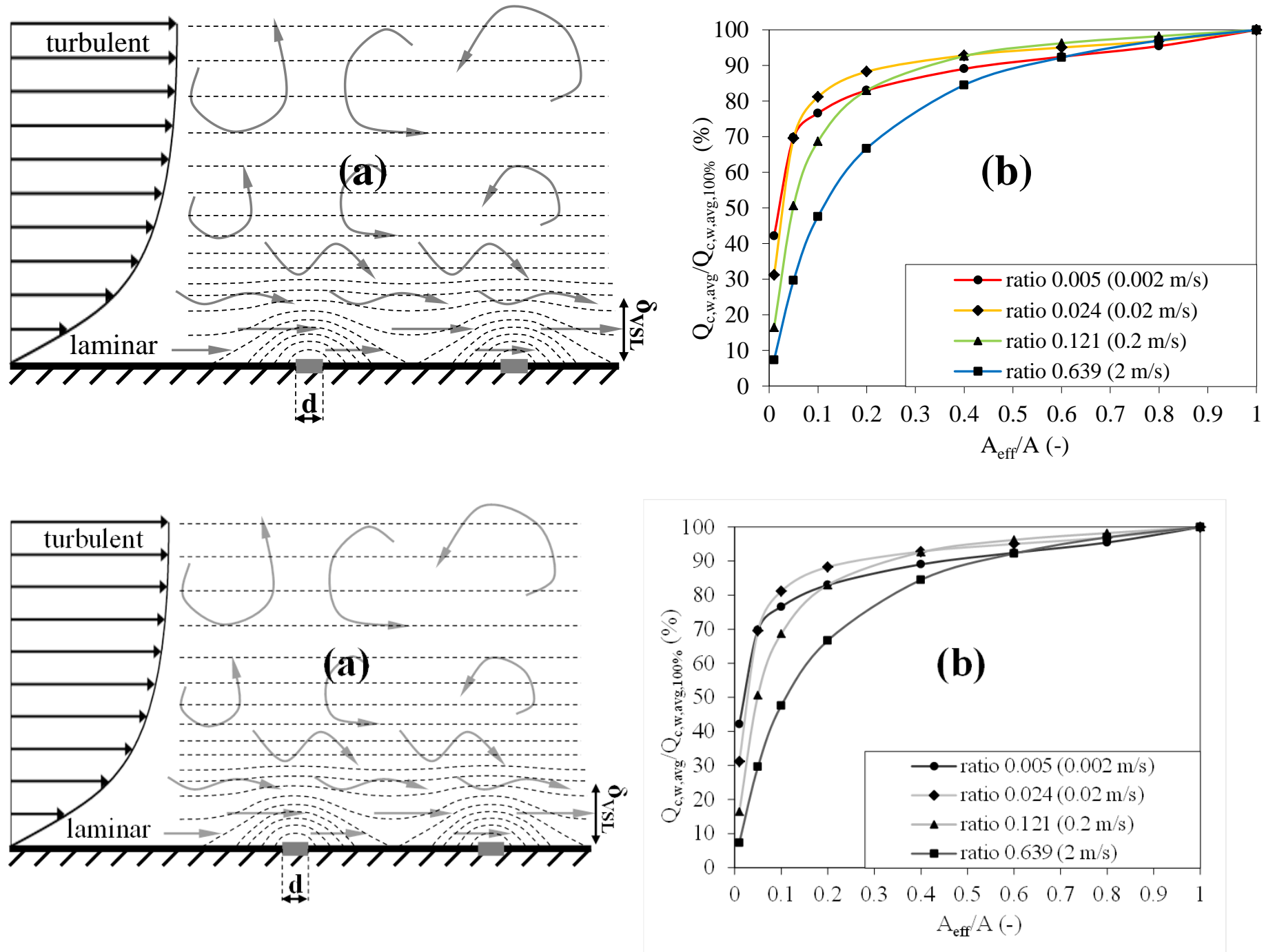

Figure 4. (a) Scalar (concentration) contours in the boundary layer over a surface with discretely-distributed patches (i.e.,, moisture sources, indicated in grey) with indication of $d$ (source size) and $\delta_{V S L}$ (viscous sublayer thickness) and also laminar and turbulent regions in the boundary layer. (b) Surface-averaged heat flow of a sphere $\left(Q_{c, w, a v g}\right)$ as a function of the surface coverage ratio $\left(A_{e f f} A\right.$, with $A_{\text {eff }}$ the surface area of the sources and $A$ the total surface area of the sphere) for different $d / \delta_{V S L}$ ratios (i.e., air speeds $U_{\text {ref }}$ ), obtained from CFD simulations. The heat flow is scaled with that of a surface with a coverage ratio of $100 \%\left(Q_{c, w, a v g, 100 \%}\right)$. Note that heat is used to model passive scalar transport, but is also representative for moisture transfer. Data taken from Defraeye et al. (2012a).

Only for colour reproduction online, not in print (black and white). $\underline{\text { A black and white figure has been provided below }}$ the colour figure. 
Defraeye T., Verboven P., Ho Q.T., Nicolai B., Convective heat and mass exchange predictions at leaf surfaces: applications, methods and perspectives, Computers and Electronics in Agriculture 96, 180-201. http://dx.doi.org/10.1016/j.compag.2013.05.008

Tables 
Table 1. Characteristics of field experiments on convective scalar transfer from leaves.

\begin{tabular}{|c|c|c|c|c|c|c|c|c|c|c|c|c|c|}
\hline Author & Setup & Leaf type & $\begin{array}{l}\text { Morphology and } \\
\text { size }\end{array}$ & Method & $\begin{array}{l}\text { Measured parameter } \\
\text { and technique }\end{array}$ & Leaf material & $\begin{array}{l}\text { Leaf } \\
\text { status }\end{array}$ & Boundary conditions & Measurement location & $\begin{array}{l}\text { Air speed } \\
\left({ }^{(}\right)\end{array}$ & Temp. & Correlation & $\begin{array}{l}\text { Remarks, aims, } \\
\text { keywords }\end{array}$ \\
\hline $\begin{array}{l}\text { Knoerr and } \\
\text { Gay (1965) }\end{array}$ & $\begin{array}{l}\text { greenh. \& } \\
\text { above roof }\end{array}$ & $\begin{array}{l}5 \text { real leaves (black } \\
\text { oak, magnolia, } \\
\text { cherry laurel) }\end{array}$ & $\begin{array}{l}\text { actual shapes }(\sim \\
28-100 \mathrm{~mm})\end{array}$ & HBM & $\begin{array}{l}\text { heat (radiometer) \& } \\
\text { mass (potometer) }\end{array}$ & $\begin{array}{l}\text { leaves (normal \& sealed } \\
\text { with wax) }\end{array}$ & free & natural environment & $\begin{array}{l}\text { individual leaves } 1 \mathrm{~m} \\
\text { above ground of greenh. } \\
\& 1 \mathrm{~m} \text { above roof }\end{array}$ & $0-4.25 \mathrm{~m} / \mathrm{s}$ & $\begin{array}{l}T_{a m b}=33.5- \\
41^{\circ} \mathrm{C}\end{array}$ & - & $\begin{array}{l}\text { transpiring \& non- } \\
\text { transpiring leaves; flow } \\
\text { regime }\end{array}$ \\
\hline Sinclair (1970) & greenh. & $\begin{array}{l}2 \text { real leaves (arid- } \\
\text { zone species) }\end{array}$ & $\begin{array}{l}\text { elliptical (44- } \\
92 \times 6-12 \mathrm{~mm}) \\
\end{array}$ & HBM, PM & $\begin{array}{l}\text { heat (multiple TC) } \\
\& \text { mass (potometer) }\end{array}$ & leaves & free & $\begin{array}{l}\text { natural environment, air } \\
\text { flow by fans }\end{array}$ & $\begin{array}{l}\text { individual leaves } 0.2 \mathrm{~m} \\
\text { above ground }\end{array}$ & $0-2.4 \mathrm{~m} / \mathrm{s}$ & - & - & $\begin{array}{l}\text { narrow leaves; field } \\
\text { validation study }\end{array}$ \\
\hline $\begin{array}{l}\text { Parlange and } \\
\text { Waggoner } \\
(1972)\end{array}$ & crop canopy & 2 real leaves (reed) & $\begin{array}{l}\text { elliptical (31- } \\
\text { 33mm wide) }\end{array}$ & HBM & heat (liquid crystals) & leaves (painted black) & $\begin{array}{l}\text { fixed \& } \\
\text { free }\end{array}$ & natural environment & inside canopy & $0.1-4 \mathrm{~m} / \mathrm{s}$ & $\begin{array}{l}T_{a m b} \approx 27- \\
31^{\circ} \mathrm{C}\end{array}$ & $N u_{x}=0.332 \beta \operatorname{Re}^{1 / 2} \operatorname{Pr}^{1 / 3}(\beta \approx 2.5)$ & flow regime \\
\hline $\begin{array}{l}\text { Pearman et al. } \\
(1972)\end{array}$ & crop canopy & artif. leaves & $\begin{array}{l}\text { disks (diam. 19- } \\
127 \mathrm{~mm})\end{array}$ & $\begin{array}{l}\text { HBM, } \\
\text { HBM-TS, } \\
\text { CCT }\end{array}$ & heat $(1 \mathrm{TC})$ & $\begin{array}{l}\text { alu. (painted white \& } \\
\text { unpainted) \& copper }\end{array}$ & fixed & $\begin{array}{l}\text { H: electric. heat. (int.), } \\
\text { conductively (ext.) }\end{array}$ & $\begin{array}{l}\text { inside canopy, at } \\
\text { different heights }\end{array}$ & $0.1-3.5 \mathrm{~m} / \mathrm{s}$ & $\Delta T=0.5-5^{\circ} \mathrm{C}$ & $N u_{d}=1.08 \operatorname{Re}_{d}^{1 / 2} \mathrm{Pr}^{1 / 3}$ & $\begin{array}{l}\text { comparison of steady \& } \\
\text { unsteady techniques; leaf } \\
\text { size; height in canopy }\end{array}$ \\
\hline $\begin{array}{l}\text { Thorpe and } \\
\text { Butler (1977) }\end{array}$ & orchard & $\begin{array}{l}15 \text { real leaves } \\
\text { (apple) }\end{array}$ & $\begin{array}{l}\text { actual shapes }(45- \\
48 \mathrm{~mm})\end{array}$ & HBM-TS & heat $(1 \mathrm{TC})$ & $\begin{array}{l}\text { leaves (normal \& coated } \\
\text { with Vaseline }{ }^{\circledR} \text { ) }\end{array}$ & free & natural environment & $\begin{array}{l}\text { inside canopy, at } \\
\text { different heights }\end{array}$ & $\sim 0.2-2 \mathrm{~m} / \mathrm{s}$ & - & $N u_{L}=0.46 \operatorname{Re}_{L}{ }^{0.54} \mathrm{Pr}^{1 / 3}$ & entire tree \\
\hline $\begin{array}{l}\text { Silva et al. } \\
\text { (1988) }\end{array}$ & greenh. & $\begin{array}{l}2 \text { artif. leaves } \\
\text { (tomato) }\end{array}$ & $\begin{array}{l}\text { actual shapes } \\
(80 \times 50 \mathrm{~mm})\end{array}$ & HBM-TS & heat $(1 \mathrm{TC})$ & $\begin{array}{l}\text { alu. (black) \& alu. } \\
\text { covered with tissue } \\
\text { (black) }\end{array}$ & fixed & $\begin{array}{l}\text { H: electric. heat. (int.) } \\
\& \text { M: wet tissue }\end{array}$ & inside greenh. canopy & - & - & - & $\begin{array}{l}\text { CHTC \& CMTC; } \\
\text { greenhouse }\end{array}$ \\
\hline $\begin{array}{l}\text { Leuning and } \\
\text { Foster (1990) }\end{array}$ & tree canopy & $\begin{array}{l}\text { 9-12 real \& artif. } \\
\text { leaves (eucalyptus) }\end{array}$ & $\begin{array}{l}\text { actual shapes }(\sim \\
200 \mathrm{~mm})\end{array}$ & $\begin{array}{l}\text { HBM-TS-M, } \\
\text { HBM-TS, } \\
\text { VCT }\end{array}$ & $\begin{array}{l}\text { heat }(1 \mathrm{TC}) \& \text { mass } \\
\text { (moisture in air } \\
\text { flow) }\end{array}$ & $\begin{array}{l}\text { leaves (normal \& } \\
\text { covered with vinyl film) } \\
\text { - alu. }\end{array}$ & fixed & $\begin{array}{l}\text { real: natural } \\
\text { environment, VC \& } \\
\text { artif.: electric. heat. } \\
\text { (int.) }\end{array}$ & $\begin{array}{l}\text { inside canopy, at } \\
\text { different heights; } \\
\text { with/without VC }\end{array}$ & $<\sim 3 \mathrm{~m} / \mathrm{s}$ & $\begin{array}{l}\Delta T=1^{\circ} \mathrm{C} \\
\text { (artif.) }\end{array}$ & - & $\begin{array}{l}\text { transpiration rates; } \\
\text { ventilated chamber }\end{array}$ \\
\hline $\begin{array}{l}\begin{array}{l}\text { Roberts et al. } \\
(1990)\end{array} \\
\end{array}$ & tree canopy & $\begin{array}{l}\text { artif. leaves }(9 \\
\text { species) }\end{array}$ & actual shapes & WLT & mass (grav.) & blotting paper & free & wet blotting paper & inside canopy & $0-2.5 \mathrm{~m} / \mathrm{s}$ & - & - & $\begin{array}{l}\text { spatial \& temporal } \\
\text { variation of BLC }\end{array}$ \\
\hline $\begin{array}{l}\text { Teklehaimanot } \\
\text { and Jarvis } \\
\text { (1991) }\end{array}$ & tree canopy & $\begin{array}{l}\text { real tree (sitka } \\
\text { spruce) }\end{array}$ & actual shape & HTT & mass (grav.) & tree & free & wetted tree & inside canopy & $\begin{array}{l}0.04- \\
2.72 \mathrm{~m} / \mathrm{s}\end{array}$ & - & $\begin{array}{l}g_{b, h, L A}=a U_{A C}(a=0.0102- \\
\left.0.1219 S_{P}\right)\end{array}$ & $\begin{array}{l}\text { evaporation of } \\
\text { intercepted water; } \\
\text { storage capacity }\end{array}$ \\
\hline $\begin{array}{l}\text { Brenner and } \\
\text { Jarvis (1995) }\end{array}$ & crop canopy & 1 artif. leaf (millet) & $\begin{array}{l}\text { rectangular } \\
(35 \times 30 \mathrm{~mm})\end{array}$ & HBM-TS & heat $(3 \mathrm{TC})$ & brass (nickel plated) & fixed & electric. heat. (int.) & $0.1 \mathrm{~m}$ above canopy & $<\sim 5 \mathrm{~m} / \mathrm{s}$ & - & $\begin{array}{l}g_{b, h}=0.034 U_{A C} C^{0.52} \text { (lam.) } \\
g_{b, h}=0.023 U_{A C} C^{0.73} \text { (turb.) }\end{array}$ & $\begin{array}{l}\text { design of artif. leaves for } \\
\text { field experiments; } \\
\text { windbreak }\end{array}$ \\
\hline $\begin{array}{l}\text { Domingo et al. } \\
\text { (1996) }\end{array}$ & canopy & $\begin{array}{l}2 \text { artif. leaves } \\
\text { (cladode of bush \& } \\
\text { grass) }\end{array}$ & $\begin{array}{l}\text { cylindrical } \\
(150 \times 2 \mathrm{~mm})\end{array}$ & HBM-TS & heat $(3 \mathrm{TC})$ & $\begin{array}{l}\text { stainless steel (silver } \\
\text { painted) }\end{array}$ & fixed & electric. heat. (int.) & $\begin{array}{l}\text { inside canopy, at } \\
\text { different heights }\end{array}$ & $<\sim 4 \mathrm{~m} / \mathrm{s}$ & $\Delta T=3-9^{\circ} \mathrm{C}$ & $g_{b, h}=a U_{A C}{ }^{n}\left({ }^{a}\right)$ & height in canopy \\
\hline $\begin{array}{l}\text { Smith et al. } \\
\text { (1997b) }\end{array}$ & tree canopy & $\begin{array}{l}9 \text { artif. leaves } \\
\text { (neem) }\end{array}$ & $\begin{array}{l}\text { actual shapes } \\
(61 \times 24 \mathrm{~mm})\end{array}$ & HBM-TS & heat $(1 \mathrm{TC})$ & brass & fixed & electric. heat. (int.) & $\begin{array}{l}\text { inside canopy, at } \\
\text { different heights }\end{array}$ & $\sim 0.2-4.5 \mathrm{~m} / \mathrm{s}$ & - & $\begin{array}{l}g_{b, h, L A}=a U_{A C}{ }^{n}+b \quad(a=0.287-1.61 \\
n=0.554-0.726, b=0.282-0.522)\end{array}$ & height in tree; windbreak \\
\hline $\begin{array}{l}\text { Smith et al. } \\
\text { (1997b) }\end{array}$ & tree canopy & real tree (neem) & actual shape & HTT & mass (grav.) & tree & free & wetted tree & inside canopy & $\sim 0.2-4.5 \mathrm{~m} / \mathrm{s}$ & - & $g_{b, h, L A}=0.226 U_{A C}{ }^{1.131}+0.187$ & entire tree \\
\hline $\begin{array}{l}\text { Daudet et al. } \\
\text { (1998) }\end{array}$ & vineyard & $\begin{array}{l}6 \text { artif. leaves } \\
\text { (vine) }\end{array}$ & $\begin{array}{l}\text { actual shapes (eq. } \\
\text { diam. } 138 \mathrm{~mm} \text { ) }\end{array}$ & HBM-TS & heat $(2 \mathrm{TC})$ & $\begin{array}{l}\text { copper (chromium } \\
\text { plated) }\end{array}$ & fixed & electric. heat. (int.) & $\begin{array}{l}\text { inside canopy, at } \\
\text { different heights }\end{array}$ & $0-4.6 \mathrm{~m} / \mathrm{s}$ & - & - & $\begin{array}{l}\text { design of partially heated } \\
\text { artif. leaf }\end{array}$ \\
\hline $\begin{array}{l}\text { Daudet et al. } \\
\text { (1999) }\end{array}$ & tree canopy & $\begin{array}{l}2 \text { artif. leaves } \\
\text { (walnut) }\end{array}$ & $\begin{array}{l}\text { elliptical } \\
(112 \times 46 \mathrm{~mm})\end{array}$ & HBM-TS & heat $(1-2 \mathrm{TC})$ & $\begin{array}{l}\text { copper (chromium } \\
\text { plated) }\end{array}$ & fixed & electric. heat. (int.) & $\begin{array}{l}\text { inside canopy, at } \\
\text { different heights }\end{array}$ & $<\sim 2 \mathrm{~m} / \mathrm{s}$ & $\Delta T<14^{\circ} \mathrm{C}$ & $g_{b, h}=0.01 U_{l o c}+0.0071$ & variation of BLC in tree \\
\hline $\begin{array}{l}\text { Grantz and } \\
\text { Vaughn (1999) }\end{array}$ & crop canopy & $\begin{array}{l}10 \text { artif. leaves } \\
\text { (cotton) }\end{array}$ & $\begin{array}{l}\text { actual shapes } \\
(100-150 \mathrm{~mm})\end{array}$ & HBM-TS & heat $(4-6 \mathrm{TC})$ & brass (nickel plated) & fixed & electric. heat. (int.) & $\begin{array}{l}\text { inside canopy, at } \\
\text { different heights }\end{array}$ & - & - & - & height in canopy \\
\hline $\begin{array}{l}\text { Martin et al. } \\
\text { (1999) }\end{array}$ & tree canopy & $\begin{array}{l}6 \text { real branches } \\
\text { (silver fir) }\end{array}$ & actual shapes & HBM, RSM & $\begin{array}{l}\text { heat }(4 \mathrm{TC}-\mathrm{IRT}) \& \\
\text { mass (potometer) }\end{array}$ & branches & free & natural environment & $\begin{array}{l}\text { inside canopy, at } \\
\text { different heights }\end{array}$ & $0-2 \mathrm{~m} / \mathrm{s}$ & $\begin{array}{l}T_{a m b} \approx 18^{\circ} \mathrm{C}, \\
\Delta T<6.6^{\circ} \mathrm{C}\end{array}$ & $g_{b, m}=0.0744 U_{A C}+0.005$ & $\begin{array}{l}\text { comparison of different } \\
\text { techniques; coniferous } \\
\text { branches }\end{array}$ \\
\hline $\begin{array}{l}\text { Stokes et al. } \\
\text { (2006) }\end{array}$ & tree canopy & $\begin{array}{l}2 \text { artif. leaves (oak } \\
\& \text { sycamore) }\end{array}$ & $\begin{array}{l}\text { actual shapes (44- } \\
77 \times 120-124 \mathrm{~mm} \text {, } \\
0.1 \mathrm{~mm} \text { thick) }\end{array}$ & HBM-TS & heat (1 RTD) & Mylar® (painted white) & free & electric. heat. (int.) & $\begin{array}{l}\text { inside canopy, sunny \& } \\
\text { shaded positions }\end{array}$ & $0.3-3.5 \mathrm{~m} / \mathrm{s}$ & $\Delta T<26^{\circ} \mathrm{C}$ & $\begin{array}{l}g_{b, h}=0.01471 U_{l o c}+0.01551 \\
\text { (oak) } \\
g_{b, h}=0.01234 U_{l o c}+0.00851 \\
\text { (sycamore) }\end{array}$ & flexible leaf design \\
\hline $\begin{array}{l}\text { Kichah et al. } \\
\text { (2012) }\end{array}$ & greenh. & $\begin{array}{l}\text { entire plant } \\
\text { (impatiens) }\end{array}$ & actual shapes & WM & mass (grav.) & plant with leaves & free & natural environment & inside greenh. canopy & $<0.1 \mathrm{~m} / \mathrm{s}$ & $\begin{array}{l}T_{a m b} \approx 20- \\
30^{\circ} \mathrm{C}\end{array}$ & 1 & $\begin{array}{l}\text { transpiration rates; CFD } \\
\text { validation }\end{array}$ \\
\hline
\end{tabular}

(a): see paper for more detailed correlations

(b): inside or above canopy 
Table 2. Symbols, parameters and abbreviations used in Tables 1, 3 and 4.

\begin{tabular}{|c|c|c|c|}
\hline \multicolumn{2}{|l|}{ Abbreviations } & \multicolumn{2}{|c|}{ Symbols \& parameters } \\
\hline alu. & aluminium & $a$ & parameter \\
\hline a.o. & amongst others & $b$ & parameter \\
\hline artif. & artificial & $g_{b, h}$ & boundary-layer conductance for heat transfer $\left(\mathrm{m} \mathrm{s}^{-1}\right)$ \\
\hline const. & constant & $g_{b, m}$ & boundary-layer conductance to moisture transfer $\left(\mathrm{m} \mathrm{s}^{-1}\right)$ \\
\hline diam. & diameter & $g_{b, h, L A}$ & bulk boundary-layer conductance of entire tree, integrated over leaf area $\left(\mathrm{m}^{3} \mathrm{~s}^{-1}\right)$ \\
\hline electric. & electrically & $C$ & parameter \\
\hline electrochem. FT & electrochemical fluid tunnel & $D$ & leaf size $(\mathrm{m})$ \\
\hline eq. & equivalent & $D_{C}$ & diameter of the largest circle which can be inscribed (m) \\
\hline ext. & from exterior & $D_{m}$ & diffusion coefficient of water vapour in air $\left(\mathrm{m}^{3} \mathrm{~s}^{-1}\right)$ \\
\hline forc. & forced & $F$ & parameter \\
\hline grav. & gravimetrically & $G$ & parameter \\
\hline greenh. & greenhouse & $G r$ & Grashof number \\
\hline heat. & heated & $l$ & characteristic leaf dimension $(\mathrm{m})$ \\
\hline int. & from interior & $n$ & exponent \\
\hline lab. & laboratory setup & $N u_{B}$ & Nusselt number (surface averaged) of leaf, based on leaf width $B$ \\
\hline lam. & laminar & $N u_{d}$ & Nusselt number (surface averaged) of leaf, based on diameter of plate $d$ \\
\hline temp. & temperature & $N u_{D}$ & $\begin{array}{l}\text { Nusselt number (surface averaged) of leaf, based on leaf size } D \text { (often leaf length in } \\
\text { flow direction) }\end{array}$ \\
\hline trans. & transient & $N u_{L}$ & $\begin{array}{l}\text { Nusselt number (surface averaged) of leaf, based on weighted characteristic leaf } \\
\text { dimension } L\end{array}$ \\
\hline turb. & turbulent & $N u_{x}$ & Nusselt number (local) of leaf, based on distance from leading edge $x$ \\
\hline unif. & uniform & $P r$ & Prandtl number \\
\hline $\mathrm{AC}$ & assimilation chamber & $R_{B L}$ & boundary layer resistance for heat or mass transfer $\left(\mathrm{s} \mathrm{m}^{-1}\right)$ \\
\hline $\mathrm{CCT}$ & cooling curve technique & $R_{B L, h}$ & boundary layer resistance for heat transfer $\left(\mathrm{s} \mathrm{m}^{-1}\right)$ \\
\hline ECM & electrochemical method & $R_{B L, m}$ & boundary layer resistance for mass transfer $\left(\mathrm{s} \mathrm{m}^{-1}\right)$ \\
\hline FEM & finite element method & $\operatorname{Re}$ & Reynolds number \\
\hline FM & flux meter & $R e_{B}$ & Reynolds number based on free-stream air speed and leaf width $B$ \\
\hline FVM & finite volume method & $R e_{d}$ & Reynolds number based on free-stream air speed and diameter of plate $d$ \\
\hline $\mathrm{H}$ & heat & $R e_{D}$ & $\begin{array}{l}\text { Reynolds number based on free-stream air speed and leaf size } D \text { (often leaf length } \\
\text { in the flow direction) }\end{array}$ \\
\hline HBM & heat balance method & $R e_{L}$ & $\begin{array}{l}\text { Reynolds number based on free-stream air speed and weighted characteristic } \\
\text { dimension } L\end{array}$ \\
\hline HBM-M & heat balance method for mass transfer & $R_{v}$ & specific gas constant of water vapour $\left(\mathrm{J} \mathrm{kg}^{-1} \mathrm{~K}^{-1}\right)$ \\
\hline HBM-TS & heat balance method based on two states & Sc & Schmidt number \\
\hline HBM-TS-M & $\begin{array}{l}\text { heat balance method based on two states for } \\
\text { mass transfer }\end{array}$ & $S h_{D}$ & $\begin{array}{l}\text { Sherwood number (surface averaged) of leaf, based on leaf size } D \text { (often leaf length } \\
\text { in flow direction) }\end{array}$ \\
\hline HFM & heat flux method & $S h_{L}$ & $\begin{array}{l}\text { Sherwood number (surface averaged) of leaf, based on weighted characteristic leaf } \\
\text { dimension } L\end{array}$ \\
\hline HTT & hanging tree technique & $S_{P}$ & distance/spacing between trees $(\mathrm{m})$ \\
\hline IRT & infrared thermography & $T$ & temperature $\left(\mathrm{K}\right.$ or $\left.{ }^{\circ} \mathrm{C}\right)$ \\
\hline M & mass & $T_{a m b}$ & ambient air temperature $\left(\mathrm{K}\right.$ or $\left.{ }^{\circ} \mathrm{C}\right)$ \\
\hline $\mathrm{MC}$ & Münger cell & $U_{A C}$ & air speed above the canopy $\left(\mathrm{m} \mathrm{s}^{-1}\right)$ \\
\hline PM & potometer method & $U_{l o c}$ & local air speed close to leaf (in canopy) $\left(\mathrm{m} \mathrm{s}^{-1}\right)$ \\
\hline RSM & resistance substraction method & $U_{\infty}$ & free-stream air speed $\left(\mathrm{m} \mathrm{s}^{-1}\right)$ \\
\hline RTD & resistive temperature device & $\alpha$ & thermal diffusivity of air $\left(\mathrm{m}^{2} \mathrm{~s}^{-1}\right)$ \\
\hline SPT & Schlieren photography technique & $\beta$ & correction factor \\
\hline TC & thermocouple & $\Delta T$ & temperature difference between surface and ambient air $\left(\mathrm{K}\right.$ or $\left.{ }^{\circ} \mathrm{C}\right)$ \\
\hline TRM & thermistor & $v$ & kinematic viscosity $\left(\mathrm{m}^{2} \mathrm{~s}^{-1}\right)$ \\
\hline $\mathrm{VC}$ & ventilated chamber & & \\
\hline VCT & ventilated chamber technique & & \\
\hline WLT & water loss technique & & \\
\hline WM & weighing method & & \\
\hline WT & wind tunnel & & \\
\hline
\end{tabular}


Table 3. Characteristics of laboratory experiments on convective scalar transfer from leaves.

\begin{tabular}{|c|c|c|c|c|c|c|c|c|c|c|c|c|c|c|}
\hline Author & Setup & Leaf type & Morphology and size & Method & $\begin{array}{l}\text { Measured parameter } \\
\text { and method }\end{array}$ & Leaf material & $\begin{array}{l}\text { Leaf } \\
\text { status }\end{array}$ & Boundary conditions & $\begin{array}{l}\text { Flow } \\
\text { configuration }\end{array}$ & Flow regime & $U_{\infty}, R e$ or $G r$ & Temp. & Correlation & Remarks, aims, keywords \\
\hline $\begin{array}{l}\text { Gates and } \\
\text { Benedict } \\
\text { (1963) }\end{array}$ & lab. & $\begin{array}{l}6 \text { real leaves \& } 2 \\
\text { real coniferous } \\
\text { branches }\end{array}$ & actual shape & SPT & $\begin{array}{l}\text { heat }(1 \mathrm{TC} \& \\
\text { radiometer) }\end{array}$ & $\begin{array}{l}\text { branches \& } \\
\text { leaves }\end{array}$ & fixed & heated with sun gun (ext.) & $\begin{array}{l}\text { forc.: parallel, } \\
\text { free: horizontal, } \\
\text { inclined \& } \\
\text { vertical }\end{array}$ & $\begin{array}{l}\text { free \& } \\
\text { mixed }\end{array}$ & $0-0.45 \mathrm{~m} / \mathrm{s}$ & - & - & $\begin{array}{l}\text { natural convection; quantitative } \\
\text { SPT }\end{array}$ \\
\hline $\begin{array}{l}\text { Tibbals et al. } \\
\text { (1964) }\end{array}$ & WT & $\begin{array}{l}2 \text { artif. branches } \\
\text { (blue spruce \& } \\
\text { white fir) }\end{array}$ & actual shapes & CCT & heat (multiple TC) & silver (casting) & fixed & radiant heater (ext.) & $\begin{array}{l}\text { parallel \& } \\
\text { perpendicular }\end{array}$ & $\begin{array}{l}\text { free, mixed } \\
\& \text { forc. }\end{array}$ & $0.4-1.4 \mathrm{~m} / \mathrm{s}$ & $\Delta T<33^{\circ} \mathrm{C}$ & $\begin{array}{l}h_{h}=7.264 T^{0.25} \text { (free-fir) } \\
h_{h}=14.2+1.95 U_{\infty}^{0.75} \text { (forc.-fir- } \\
\text { parallel) }{ }^{\left({ }^{a}\right)} \text { ( }\end{array}$ & flow regime \\
\hline $\begin{array}{l}\text { Gates et al. } \\
(1965)\end{array}$ & WT & $\begin{array}{l}1 \text { artif. branch } \\
\text { (pine) }\end{array}$ & actual shape & CCT & heat (multiple TC) & silver (casting) & fixed & radiant heater (ext.) & $\begin{array}{l}\text { parallel \& } \\
\text { perpendicular }\end{array}$ & $\begin{array}{l}\text { free, mixed } \\
\& \text { forc. }\end{array}$ & $0-1.2 \mathrm{~m} / \mathrm{s}$ & - & $\begin{array}{l}h_{h}=7.68+2.51 \Delta T^{0.3} \text { (free) } \\
h_{h}=12.6+0.495 U_{\infty} \text { (forc.) }\end{array}$ & flow regime \\
\hline $\begin{array}{l}\text { Pearman } \\
(1965)\end{array}$ & WT & $\begin{array}{l}\text { real leaves } \\
\text { (Hottentot fig) }\end{array}$ & $\begin{array}{l}\text { actual shapes }(50- \\
70 \mathrm{~mm})\end{array}$ & CCT & $\begin{array}{l}\text { heat (1 TC inside } \\
\text { leaf) }\end{array}$ & leaf & fixed & microwave radiation (ext.) & not specified & $\begin{array}{l}\text { free, mixed } \\
\& \text { forc. }\end{array}$ & $0-3 \mathrm{~m} / \mathrm{s}$ & $\Delta T \approx 7^{\circ} \mathrm{C}$ & - & flow regime \\
\hline Linacre (1967) & lab. & 1 artif. leaf & rectangular $\left(64.5 \mathrm{~cm}^{2}\right)$ & CCT & $\begin{array}{l}\text { heat (1 TC) \& mass } \\
\text { (grav.) }\end{array}$ & blotting paper & fixed & lamp heating (ext.) & no flow, vertical & free & - & $T_{a m b}=20^{\circ} \mathrm{C}$ & $R_{B L}{ }^{3}+C R_{B L}{ }^{2}+F R_{B L}=G\left({ }^{\mathrm{a}}\right)$ & $\begin{array}{l}\text { natural convection; transpiring } \\
\text { leaf }\end{array}$ \\
\hline $\begin{array}{l}\text { Parkhurst et al. } \\
\text { (1968) }\end{array}$ & WT & 10 artif. leaves & $\begin{array}{l}\text { elliptical \& other } \\
\text { models }\end{array}$ & HBM & heat (multiple TC) & $\begin{array}{l}\text { copper sheet } \\
\text { (black) }\end{array}$ & $\begin{array}{l}\text { fixed \& } \\
\text { free }\end{array}$ & electric. heat. (int.) & $\begin{array}{l}\text { parallel \& } \\
\text { oblique }\end{array}$ & $\begin{array}{l}\text { free, mixed } \\
\& \text { forc. }\end{array}$ & $\begin{array}{l}R e_{L} \approx 1600- \\
20000\end{array}$ & - & - & $\begin{array}{l}\text { broad leaves; leaf shape; } \\
\text { characteristic dimensions }\end{array}$ \\
\hline Thom (1968) & WT & $\begin{array}{l}1 \text { artif. leaf } \\
\text { (bean) }\end{array}$ & $\begin{array}{l}\text { elliptical } \\
\text { (42x66x5mm) }\end{array}$ & $\begin{array}{l}\text { HBM, } \\
\text { WLT }\end{array}$ & $\begin{array}{l}\text { heat (2 TC) \& mass } \\
\text { (grav.) }\end{array}$ & $\begin{array}{l}\text { alu. (covered } \\
\text { with filter } \\
\text { paper) }\end{array}$ & fixed & $\begin{array}{l}\text { H: electric. heat. (int.) \& } \\
\text { M: wet filter paper }\end{array}$ & $\begin{array}{l}\text { parallel \& } \\
\text { oblique }\end{array}$ & $\begin{array}{l}\text { mixed \& } \\
\text { forc. }\end{array}$ & $0.2-1.5 \mathrm{~m} / \mathrm{s}$ & $\Delta T \approx 1^{\circ} \mathrm{C}$ & $h_{h} \sim U_{\infty}^{0.5}$ & $\begin{array}{l}\text { relation between drag \& } \\
\text { heat/mass transfer }\end{array}$ \\
\hline $\begin{array}{l}\text { Landsberg and } \\
\text { Ludlow (1970) }\end{array}$ & $\begin{array}{l}\text { WT \& } \\
\text { AC }\end{array}$ & $\begin{array}{l}7 \text { real spruce } \\
\text { shoots }\end{array}$ & actual shapes & $\begin{array}{l}\text { WLT, } \\
\text { VCT }\end{array}$ & $\begin{array}{l}\text { mass (grav. \& } \\
\text { moisture in air flow) }\end{array}$ & $\begin{array}{l}\text { shoots (plaster- } \\
\text { coated) }\end{array}$ & fixed & wet plaster & $\begin{array}{l}\text { perpendicular to } \\
\text { shoot }\end{array}$ & $\begin{array}{l}\text { mixed \& } \\
\text { forc. }\end{array}$ & $0.35-5.5 \mathrm{~m} / \mathrm{s}$ & - & $R_{B L, m}=0.04+1.27 \mathrm{U}_{\infty}^{-0.5}$ & coniferous species \\
\hline Sinclair (1970) & WT & $\begin{array}{l}4 \text { artif. leaves } \\
\text { (arid-zone } \\
\text { species) }\end{array}$ & $\begin{array}{l}\text { elliptical }(40-80 \times 4.4- \\
12 \mathrm{~mm})\end{array}$ & HBM & heat (1 TC) & $\begin{array}{l}\text { copper } \\
\text { (polished) }\end{array}$ & fixed & electric. heat. (int.) & $\begin{array}{l}\text { forc.: parallel \& } \\
\text { perpendicular, } \\
\text { free: horizontal } \\
\& \text { vertical }\end{array}$ & free \& forc. & $0-1.3 \mathrm{~m} / \mathrm{s}$ & $\Delta T=0-55^{\circ} \mathrm{C}$ & 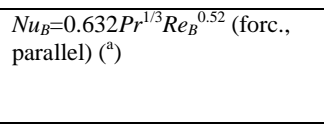 & $\begin{array}{l}\text { narrow leaves; flow regime; } \\
\text { comparison with engineering } \\
\text { correlations }\end{array}$ \\
\hline Vogel (1970) & WT & $\begin{array}{l}7 \text { artif. leaves } \\
\text { (a.o. oak) \& } 1 \\
\text { real leaf (oak) }\end{array}$ & $\begin{array}{l}\text { circles, abstract shapes } \\
\& \text { actual shape } \\
(0.25 \mathrm{~mm} \text { thick })\end{array}$ & HBM & heat (1 TRM) & copper, leaf & fixed & $\begin{array}{l}\text { electric. heat. (int., in leaf } \\
\text { centre) \& lamp heating } \\
\text { (ext.) }\end{array}$ & $\begin{array}{l}\text { parallel \& } \\
\text { oblique }\end{array}$ & $\begin{array}{l}\text { free, mixed } \\
\& \text { forc. }\end{array}$ & $0-0.3 \mathrm{~m} / \mathrm{s}$ & $\begin{array}{l}T_{a m b}=23^{\circ} \mathrm{C} \\
\Delta T=15^{\circ} \mathrm{C}\end{array}$ & - & $\begin{array}{l}\text { leaf shape (lobbing); flow } \\
\text { orientation; flow regime }\end{array}$ \\
\hline $\begin{array}{l}\text { Kumar and } \\
\text { Barthakur } \\
\text { (1971) }\end{array}$ & WT & $\begin{array}{l}\text { real leaves on } \\
\text { plant (bean, } \\
\text { Peperomia \& } \\
\text { egg plant) }\end{array}$ & actual shapes & $\begin{array}{l}\text { HBM, } \\
\text { CCT, } \\
\text { WM }\end{array}$ & $\begin{array}{l}\text { heat (1 TC inside } \\
\text { leaf) \& mass (grav.) }\end{array}$ & $\begin{array}{l}\text { plant with } \\
\text { leaves }\end{array}$ & free & microwave radiation (ext.) & $\begin{array}{l}\text { perpendicular to } \\
\text { plant }\end{array}$ & free \& forc. & $0-6.1 \mathrm{~m} / \mathrm{s}$ & - & - & $\begin{array}{l}\text { comparison of analytical, } \\
\text { steady \& unsteady methods; } \\
\text { flow regime }\end{array}$ \\
\hline $\begin{array}{l}\text { Parlange et al. } \\
\text { (1971) }\end{array}$ & $\begin{array}{l}\text { lab. } \\
\text { (fan) }\end{array}$ & $\begin{array}{l}1 \text { real leaf } \\
\text { (tobacco) }\end{array}$ & $\begin{array}{l}\text { square (cut to } \\
200 \times 200 \mathrm{~mm} \text { ) }\end{array}$ & $\begin{array}{l}\text { HBM, } \\
\text { CCT }\end{array}$ & $\begin{array}{l}\text { heat (multiple TC, } \\
\text { radiometer, liquid } \\
\text { crystals) \& mass } \\
\text { (grav.) }\end{array}$ & leaf & $\begin{array}{l}\text { fixed \& } \\
\text { semi free }\end{array}$ & lamp heating (ext.) & parallel & $\begin{array}{l}\text { mixed \& } \\
\text { forc. }\end{array}$ & $0.6-1.6 \mathrm{~m} / \mathrm{s}$ & $\Delta T=5-10^{\circ} \mathrm{C}$ & $\begin{array}{l}N u_{x}=0.332 \beta \operatorname{Re}^{1 / 2} \operatorname{Pr}^{1 / 3}(\beta \approx \\
2.4-2.7)\end{array}$ & $\begin{array}{l}\text { fluttering (mechanically } \\
\text { induced); temp. distribution } \\
\text { across leaf }\end{array}$ \\
\hline $\begin{array}{l}\text { Saldin and } \\
\text { Barthakur } \\
\text { (1971) }\end{array}$ & WT & $\begin{array}{l}\text { real leaves on } \\
\text { plant (bean) }\end{array}$ & $\begin{array}{l}\text { actual shapes }(60- \\
120 \times 40-100 \mathrm{~mm})\end{array}$ & $\begin{array}{l}\text { HBM, } \\
\text { CCT }\end{array}$ & $\begin{array}{l}\text { heat (1 TC inside } \\
\text { leaf) \& mass (grav.) }\end{array}$ & $\begin{array}{l}\text { plant with } \\
\text { leaves }\end{array}$ & free & microwave radiation (ext.) & $\begin{array}{l}\text { perpendicular to } \\
\text { plant }\end{array}$ & free \& forc. & $0-6.85 \mathrm{~m} / \mathrm{s}$ & - & - & $\begin{array}{l}\text { comparison of steady \& } \\
\text { unsteady methods }\end{array}$ \\
\hline $\begin{array}{l}\text { Schuepp } \\
\text { (1972) }\end{array}$ & $\begin{array}{l}\text { electroc } \\
\text { hem. } \\
\text { FT }\end{array}$ & 7 real leaves & $\begin{array}{l}\text { actual shapes }(30- \\
60 \mathrm{~mm})\end{array}$ & ECM & $\begin{array}{l}\text { mass (concentration } \\
\text { difference from } \\
\text { electric current) }\end{array}$ & $\begin{array}{l}\text { leaves (nickel- } \\
\text { coated) }\end{array}$ & $\begin{array}{l}\text { free \& } \\
\text { fixed }\end{array}$ & $\begin{array}{l}\text { const. concentration of } \\
\text { ferricyanide ions at } \\
\text { surface }\end{array}$ & parallel & forc. & $0.06-1.2 \mathrm{~m} / \mathrm{s}$ & - & $\begin{array}{l}S h_{L}=0.66 \beta \operatorname{Re}_{L}^{1 / 2} S c^{1 / 3}(\beta \approx 1.2- \\
1.8)\end{array}$ & fluttering; leaf interference \\
\hline $\begin{array}{l}\text { Landsberg and } \\
\text { Powell (1973) }\end{array}$ & WT & artif. tree (apple) & actual shape & WLT & mass (grav.) & $\begin{array}{l}\text { alu. (covered } \\
\text { with blotting } \\
\text { paper) }\end{array}$ & free & wet blotting paper & $\begin{array}{l}\text { perpendicular to } \\
\text { tree }\end{array}$ & $\begin{array}{l}\text { mixed \& } \\
\text { forc. }\end{array}$ & $0.5-4 \mathrm{~m} / \mathrm{s}$ & $\Delta T<2^{\circ} \mathrm{C}$ & $h_{m}=a /\left(R_{v} T\right) U_{\infty}{ }^{1-n}\left({ }^{\mathrm{a}}\right)$ & leaf interference; leaf density \\
\hline $\begin{array}{l}\text { Schuepp } \\
\text { (1973) }\end{array}$ & $\begin{array}{l}\text { electroc } \\
\text { hem. } \\
\text { FT } \\
\end{array}$ & $\begin{array}{l}2 \text { artif. branches, } \\
2 \text { artif. leaves \& } \\
7 \text { real leaves }\end{array}$ & $\begin{array}{l}\text { square }(20-70 \mathrm{~mm}) \& \\
\text { actual shapes } \\
(\sim 40 \mathrm{~mm})\end{array}$ & ECM & $\begin{array}{l}\text { mass (concentration } \\
\text { difference from } \\
\text { electric current) }\end{array}$ & $\begin{array}{l}\text { nickel \& leaves } \\
\text { (nickel-coated) }\end{array}$ & fixed & $\begin{array}{l}\text { const. concentration of } \\
\text { copper ions at surface }\end{array}$ & $\begin{array}{l}\text { no flow, } \\
\text { horizontal \& } \\
\text { vertical }\end{array}$ & free & $G r=10^{5}-10^{7}$ & - & $\begin{array}{l}S h_{L}=a S^{0.25} G^{0.25} \text { (plate: } \\
a=0.52 \text {, plant: } a=0.65)\end{array}$ & $\begin{array}{l}\text { leaf shape; roughness; leaf } \\
\text { orientation }\end{array}$ \\
\hline $\begin{array}{l}\text { Parkhurst and } \\
\text { Pearman } \\
\text { (1974) }\end{array}$ & WT & 1 artif. leaf & $\begin{array}{l}\text { rectangular } \\
(40 \times 102 \times 0.3 \mathrm{~mm})\end{array}$ & HBM & heat (6 TC) & fiberglass & fixed & electric. heat. (int.) & $\begin{array}{l}\text { parallel \& } \\
\text { oblique }\end{array}$ & forc. & $3.2 \mathrm{~m} / \mathrm{s}$ & $\Delta T=3-8^{\circ} \mathrm{C}$ & - & inclination; turb. intensity \\
\hline $\begin{array}{l}\text { Wigley and } \\
\text { Clark (1974) }\end{array}$ & WT & $\begin{array}{l}1 \text { artif. leaf } \\
\text { (runner bean) }\end{array}$ & broad $(\sim 100 \mathrm{~mm})$ & HBM & heat (IRT) & perspex & fixed & electric. heat. (int.) & $\begin{array}{l}\text { parallel \& } \\
\text { oblique }\end{array}$ & forc. & $0.7-5 \mathrm{~m} / \mathrm{s}$ & $\Delta T \sim 15^{\circ} \mathrm{C}$ & $\begin{array}{l}N u_{D}=0.453 P_{P r^{1 / 3}} R_{e_{D}}^{0.5}(\mathrm{lam} .) \\
N u_{D}=0.045 P^{1 / 3} \operatorname{Re}_{D}{ }^{0.84} \text { (turb.) } \\
\text { (parallel) }\end{array}$ & broad leaves \\
\hline $\begin{array}{l}\text { Igbal and } \\
\text { Stoffers (1975) }\end{array}$ & $\begin{array}{l}\text { lab. } \\
\text { (greenh } \\
\text {.) }\end{array}$ & 2 artif. leaves & square $(80 \times 80 \mathrm{~mm})$ & HBM & heat (1 TC) & $\begin{array}{l}\text { copper \& paper } \\
\text { sheet (white) }\end{array}$ & fixed & electric. heated (int.) & no flow, vertical & free & $\begin{array}{l}G r=0.6 \times 10^{8}- \\
4 \times 10^{8}\end{array}$ & - & $\begin{array}{l}N u_{d}=1.045 G G G^{0.184} \text { (unif. flux) } \\
N u_{d}=0.648 r^{0.214} \text { (unif. temp) }\end{array}$ & $\begin{array}{l}\text { plant spacing in greenhouse; } \\
\text { natural convection }\end{array}$ \\
\hline $\begin{array}{l}\text { Balding and } \\
\text { Cunningham } \\
\text { (1976) }\end{array}$ & WT & $\begin{array}{l}2 \text { artif. leaves } \\
\text { (simple \& } \\
\text { pinnate) }\end{array}$ & $\begin{array}{l}\text { rectangular (1-60x1- } \\
60 \mathrm{~mm}, 0.1 \mathrm{~mm} \text { thick) }\end{array}$ & HBM & heat (1 TRM) & $\begin{array}{l}\text { silver foil } \\
\text { between black } \\
\text { filter paper }\end{array}$ & fixed & lamp heating (ext.) & $\begin{array}{l}\text { parallel \& } \\
\text { oblique }\end{array}$ & mixed & $0.5-2.63 \mathrm{~m} / \mathrm{s}$ & - & $\left({ }^{a}\right)$ & pinnate leaves \\
\hline
\end{tabular}




\begin{tabular}{|c|c|c|c|c|c|c|c|c|c|c|c|c|c|c|}
\hline $\begin{array}{l}\text { Grace and } \\
\text { Wilson (1976) }\end{array}$ & WT & $\begin{array}{l}1 \text { artif. leaf } \\
\text { (populus) }\end{array}$ & actual shape $(80 \mathrm{~mm})$ & WLT & mass (grav.) & $\begin{array}{l}\text { filter paper on } \\
\text { alu. plate }\end{array}$ & fixed & wet filter paper & parallel & $\begin{array}{l}\text { mixed \& } \\
\text { forc. }\end{array}$ & $0.5-10.2 \mathrm{~m} / \mathrm{s}$ & $T_{a m b}=20^{\circ} \mathrm{C}$ & $\begin{array}{l}S_{L} \approx 0.032 \beta \operatorname{Re}^{0.8}(\beta \approx 2.5) \\
\text { (turb.) } \\
S h_{L} \approx 0.56 \beta \operatorname{Re}^{0.5}(\beta \approx 2.5) \\
\text { (lam.) }\end{array}$ & $\begin{array}{l}\text { leaf boundary-layer flow } \\
\text { regime }\end{array}$ \\
\hline $\begin{array}{l}\text { Murphy and } \\
\text { Knoerr (1977) }\end{array}$ & WT & 14 real leaves & $\begin{array}{l}\text { actual shapes }(25- \\
98 \mathrm{~mm})\end{array}$ & $\begin{array}{l}\text { HBM, } \\
\text { WLT }\end{array}$ & $\begin{array}{l}\text { heat (3 TC) \& mass } \\
\text { (grav.) }\end{array}$ & $\begin{array}{l}\text { leaves covered } \\
\text { with nylon } \\
\text { mesh }\end{array}$ & free & wet leaf & parallel & mixed & $\begin{array}{l}R e_{D} \approx 500- \\
7000\end{array}$ & - & $\begin{array}{l}N u_{D}=0.89 P^{1 / 3} \operatorname{Re}_{D}^{0.5}\left({ }^{b}\right) \\
S h_{D}=0.93 \mathrm{Sc}^{1 / 3} \operatorname{Re}_{D}^{0.5}\end{array}$ & $\begin{array}{l}\text { simultaneous measurement of } \\
\text { CHTC \& CMTC; wet leaves }\end{array}$ \\
\hline $\begin{array}{l}\text { Grace et al. } \\
(1980)\end{array}$ & WT & $\begin{array}{l}7 \text { artif. leaves (3 } \\
\text { timber species) }\end{array}$ & $\begin{array}{l}\text { actual shapes }(\sim 100- \\
200 \mathrm{~mm})\end{array}$ & CCT & heat (3 TC) & $\begin{array}{l}\text { brass } \\
\text { (polished) }\end{array}$ & fixed & radiant heater (ext.) & $\begin{array}{l}\text { parallel \& } \\
\text { oblique }\end{array}$ & $\begin{array}{l}\text { free, mixed } \\
\& \text { forc. }\end{array}$ & $0-7.7 \mathrm{~m} / \mathrm{s}$ & $T_{a m b}=17^{\circ} \mathrm{C}$ & - & leaf shape; leaf orientation \\
\hline $\begin{array}{l}\text { Schuepp } \\
\text { (1980) }\end{array}$ & WT & $\begin{array}{l}3 \text { plates (flush } \\
\text { with wall) }\end{array}$ & $\begin{array}{l}\text { square }(282 \times 20.9 \& \\
50 \times 50 \mathrm{~mm}) \& \text { circular } \\
\text { (diam. } 65 \mathrm{~mm})\end{array}$ & $\begin{array}{l}\text { HFM, } \\
\text { CCT, } \\
\text { WLT }\end{array}$ & $\begin{array}{l}\text { heat (1 TRM, 1 FM) } \\
\& \text { mass (grav.) }\end{array}$ & $\begin{array}{l}\text { copper, alu. \& } \\
\text { filter paper }\end{array}$ & fixed & $\begin{array}{l}\text { H: electric. heat. (int.) \& } \\
\text { M: wet paper }\end{array}$ & parallel & $\begin{array}{l}\text { free, mixed } \\
\& \text { forc. }\end{array}$ & $0-4.2 \mathrm{~m} / \mathrm{s}$ & $\Delta T=5-20^{\circ} \mathrm{C}$ & $N u_{d}=0.7 \operatorname{Pr}^{0.25} \mathrm{Gr}^{0.25}$ (free) & intermittent air flow \\
\hline $\begin{array}{l}\text { Morrison and } \\
\text { Barfield (1981) }\end{array}$ & WT & $\begin{array}{l}1 \text { artif. \& } 1 \text { real } \\
\text { leaf (tobacco) }\end{array}$ & $\begin{array}{l}\text { elliptical (100mm, } \\
0.42 \mathrm{~mm} \text { thick) }\end{array}$ & HBM & heat $(6 \mathrm{TC})$ & $\begin{array}{l}\text { leaf \& filter } \\
\text { paper covered } \\
\text { with porous } \\
\text { teflon } \\
\text { membrane } \\
\text { (black) }\end{array}$ & fixed & $\begin{array}{l}\text { H: lamp heating (ext.) \& } \\
\text { M: wet filter paper }\end{array}$ & parallel & $\begin{array}{l}\text { free, mixed } \\
\& \text { forc. }\end{array}$ & $1-3 \mathrm{~m} / \mathrm{s}$ & $\begin{array}{l}T_{a m b}=25- \\
35^{\circ} \mathrm{C}\end{array}$ & $\begin{array}{l}N u_{x}=0.152 G r^{1 / 4} \operatorname{PrI}^{1 / 4} \text { (free) } \\
N u_{x}=0.328 e^{1 / 2} \operatorname{Pr}^{1 / 3} \text { (forc.) }\end{array}$ & $\begin{array}{l}\text { design of artif. transpiring leaf; } \\
\text { comparison with real leaf }\end{array}$ \\
\hline $\begin{array}{l}\text { Gottschlich } \\
\text { and Smith } \\
\text { (1982) }\end{array}$ & WT & 9 artif. leaves & $\begin{array}{l}\text { elliptical \& serrated } \\
(\sim 100 \mathrm{~mm})\end{array}$ & HBM & heat (2 TC) & copper & fixed & lamp heating (ext.) & parallel & forc. & $4.2 \mathrm{~m} / \mathrm{s}$ & - & $h_{h}=11.3\left(U_{\infty} / D_{C}\right)^{0.5}$ & leaf serration \\
\hline $\begin{array}{l}\text { Dixon and } \\
\text { Grace (1983) }\end{array}$ & WT & 6 artif. leaves & $\begin{array}{l}\text { rectangular \& actual } \\
\text { shapes }(0.5 \mathrm{~mm} \text { thick })\end{array}$ & HBM & heat (1 TC) & brass & fixed & electric. heat. (int.) & $\begin{array}{l}\text { no flow, } \\
\text { horizontal \& } \\
\text { vertical }\end{array}$ & free & - & $\begin{array}{l}T_{a m b}=15- \\
22^{\circ} \mathrm{C}, \Delta T=1- \\
10^{\circ} \mathrm{C}\end{array}$ & $\left.N u_{D}=a P r^{n} G r{ }^{(a)}\right)$ & $\begin{array}{l}\text { natural convection; comparison } \\
\text { with engineering correlations }\end{array}$ \\
\hline $\begin{array}{l}\text { Dixon and } \\
\text { Grace (1984) }\end{array}$ & WT & $\begin{array}{l}\text { artif. leaves \& } \\
\text { real plants (4 } \\
\text { species) }\end{array}$ & $\begin{array}{l}\text { actual shapes }(0.1- \\
0.25 \mathrm{~mm} \text { thick }) \& \\
\text { actual plants }\end{array}$ & $\begin{array}{l}\text { CCT, } \\
\text { WM }\end{array}$ & $\begin{array}{l}\text { heat (multiple TC) } \\
\& \text { mass (grav.) }\end{array}$ & $\begin{array}{l}\text { brass } \\
\text { (polished) \& } \\
\text { plants }\end{array}$ & free & lamp heating (ext.) & perpendicular & $\begin{array}{l}\text { mixed \& } \\
\text { forc. }\end{array}$ & $0.25-5 \mathrm{~m} / \mathrm{s}$ & - & $R_{B L, h}=D^{0.5} v^{0.17} /\left(0.66 D_{m}^{0.67} U_{\infty}^{0.5}\right.$ & $\begin{array}{l}\text { validity of Penman-Monteith } \\
\text { equation; leaf transpiration }\end{array}$ \\
\hline $\begin{array}{l}\text { Chen et al. } \\
\text { (1988a) }\end{array}$ & WT & 3 artif. leaves & $\begin{array}{l}\text { square }(50-100 \mathrm{~mm}, \\
0.5 \mathrm{~mm} \text { thick })\end{array}$ & HBM & heat (IRT) & alu. (black) & fixed & electric. heat. (int.) & parallel & $\begin{array}{l}\text { mixed \& } \\
\text { forc. }\end{array}$ & $0.2-2.1 \mathrm{~m} / \mathrm{s}$ & - & $N u_{D}=0.59 \beta \operatorname{Re}^{1 / 2}(\beta \approx 1.05-1.6)$ & $\begin{array}{l}\text { turb. intensity; turb. length } \\
\text { scale }\end{array}$ \\
\hline $\begin{array}{l}\text { Chen et al. } \\
\text { (1988b) }\end{array}$ & WT & 2 artif. leaves & $\begin{array}{l}\text { square }(50-70 \mathrm{~mm}, \\
0.5 \mathrm{~mm} \text { thick) }\end{array}$ & $\begin{array}{l}\text { HBM, } \\
\text { HBM- } \\
\text { M }\end{array}$ & heat (IRT) & $\begin{array}{l}\text { alu. (black) \& } \\
\text { alu. covered } \\
\text { with filter } \\
\text { paper }\end{array}$ & fixed & $\begin{array}{l}\text { H: electric. heat. (int.) \& } \\
\text { M: wet filter paper }\end{array}$ & $\begin{array}{l}\text { parallel \& } \\
\text { oblique }\end{array}$ & $\begin{array}{l}\text { mixed \& } \\
\text { forc. }\end{array}$ & $\begin{array}{l}R e_{D}=4500- \\
31300\end{array}$ & - & $\begin{array}{l}N u_{D}=0.59 \beta \operatorname{Re}^{1 / 2}(\beta \approx 1.05-1.9) \\
S h_{D}=0.66 \beta \operatorname{Sc}^{1 / 3} \operatorname{Re}^{1 / 2}(\beta \approx 0.8- \\
2.2)\end{array}$ & $\begin{array}{l}\text { turb. intensity; turb. length } \\
\text { scale; inclination; veins \& } \\
\text { serrations }\end{array}$ \\
\hline $\begin{array}{l}\text { Kitano and } \\
\text { Eguchi (1989) }\end{array}$ & $\begin{array}{l}\text { growth } \\
\text { chambe } \\
\mathrm{r}\end{array}$ & $\begin{array}{l}1 \text { artif. \& } 1 \text { real } \\
\text { leaf (cucumber) }\end{array}$ & $\begin{array}{l}\text { artif. (200mm, } 0.3 \mathrm{~mm} \\
\text { thick) \& actual shape } \\
(200 \mathrm{~mm})\end{array}$ & $\begin{array}{l}\text { HBM, } \\
\text { WM }\end{array}$ & $\begin{array}{l}\text { heat (3 TC) \& mass } \\
\text { (grav.) }\end{array}$ & $\begin{array}{l}\text { leaf \& alu. } \\
\text { (black) }\end{array}$ & fixed & $\begin{array}{l}\text { H: heated with tungsten } \\
\text { light (ext.) \& M: with } \\
\text { antitranspirant }\end{array}$ & $\begin{array}{l}\text { no flow, } \\
\text { horizontal }\end{array}$ & free & - & $T_{a m b}=25^{\circ} \mathrm{C}$ & - & dynamic response of stomata \\
\hline $\begin{array}{l}\text { Gurevitch and } \\
\text { Schuepp } \\
\text { (1990) }\end{array}$ & $\begin{array}{l}\text { electroc } \\
\text { hem. } \\
\text { FT }\end{array}$ & $\begin{array}{l}10 \text { real leaves } \\
\text { (white yarrow) }\end{array}$ & $\begin{array}{l}\text { actual shapes } \\
(\sim 50 \mathrm{~mm})\end{array}$ & ECM & $\begin{array}{l}\text { mass (concentration } \\
\text { difference from } \\
\text { electric current) }\end{array}$ & $\begin{array}{l}\text { leaves (nickel- } \\
\text { coated) }\end{array}$ & fixed & $\begin{array}{l}\text { const. concentration of } \\
\text { ferricyanide ions at } \\
\text { surface }\end{array}$ & $\begin{array}{l}\text { parallel \& } \\
\text { perpendicular }\end{array}$ & forc. & $\begin{array}{l}0.01- \\
0.26 \mathrm{~m} / \mathrm{s}\end{array}$ & - & $\begin{array}{l}\begin{array}{l}S h_{L}=a R e^{n} S c^{1 / 3}(a \approx 1.19-3.39, \\
n=0.31-0.58)\end{array}\end{array}$ & $\begin{array}{l}\text { different species; highly } \\
\text { dissected leaves; effective } \\
\text { characteristic dimensions }\end{array}$ \\
\hline $\begin{array}{l}\text { Kitano and } \\
\text { Eguchi (1990) }\end{array}$ & WT & $\begin{array}{l}1 \text { artif. leaf } \\
\text { (cucumber) }\end{array}$ & $\begin{array}{l}\text { actual shape }(115- \\
230 \mathrm{~mm}, 0.4 \mathrm{~mm} \text { thick })\end{array}$ & HBM & heat $(10 \mathrm{TC})$ & $\begin{array}{l}\text { brass } \\
\text { (polished) }\end{array}$ & fixed & electric. heat. (int.) & parallel & $\begin{array}{l}\text { mixed \& } \\
\text { forc. }\end{array}$ & $\begin{array}{l}0.075- \\
1.2 \mathrm{~m} / \mathrm{s}\end{array}$ & $\begin{array}{l}T_{a m b}=25^{\circ} \mathrm{C}, \\
\Delta T=2-20^{\circ} \mathrm{C}\end{array}$ & $\left({ }^{a}\right)$ & mixed convection \\
\hline $\begin{array}{l}\text { Bailey and } \\
\text { Meneses } \\
(1995) \\
\end{array}$ & WT & 2 artif. leaves & $\begin{array}{l}\text { elliptical }(136 \times 80 \mathrm{~mm} \\
\& 68 \times 40 \mathrm{~mm}, 1.6 \mathrm{~mm} \\
\text { thick) }\end{array}$ & HBM & heat (1 TC) & $\begin{array}{l}\text { printed circuit } \\
\text { board (alu.- } \\
\text { coated) }\end{array}$ & fixed & electric. heat. (int.) & parallel & $\begin{array}{l}\text { free, mixed } \\
\& \text { forc. }\end{array}$ & $0-0.34 \mathrm{~m} / \mathrm{s}$ & $\begin{array}{l}\Delta T=0.3- \\
42.3^{\circ} \mathrm{C}\end{array}$ & - & $\begin{array}{l}\text { flow regime; greenhouse } \\
\text { context }\end{array}$ \\
\hline $\begin{array}{l}\text { Brenner and } \\
\text { Jarvis (1995) }\end{array}$ & WT & $\begin{array}{l}1 \text { artif. leaf } \\
\text { (millet) }\end{array}$ & $\begin{array}{l}\text { rectangular } \\
(35 \times 300 \mathrm{~mm})\end{array}$ & $\begin{array}{l}\text { HBM- } \\
\text { TS, } \\
\text { WLT }\end{array}$ & $\begin{array}{l}\text { heat (3 TC) \& mass } \\
\text { (grav.) }\end{array}$ & $\begin{array}{l}\text { brass (nickel } \\
\text { plated) \& } \\
\text { blotting paper }\end{array}$ & fixed & $\begin{array}{l}\text { H: electric. heat. (int.) \& } \\
\text { M: wet blotting paper }\end{array}$ & parallel & $\begin{array}{l}\text { free, mixed } \\
\& \text { forc. }\end{array}$ & $0-11 \mathrm{~m} / \mathrm{s}$ & - & - & $\begin{array}{l}\text { design of artif. leaves for field } \\
\text { experiments }\end{array}$ \\
\hline $\begin{array}{l}\text { Kitano et al. } \\
\text { (1995) }\end{array}$ & $\begin{array}{l}\text { growth } \\
\text { chambe } \\
\mathrm{r}\end{array}$ & $\begin{array}{l}\text { entire plant } \\
\text { (cucumber \& } \\
\text { lettuce) }\end{array}$ & actual shapes & $\begin{array}{l}\text { HBM- } \\
\text { TS, } \\
\text { WM } \\
\end{array}$ & $\begin{array}{l}\text { heat (5 TC) \& mass } \\
\text { (grav.) }\end{array}$ & $\begin{array}{l}\text { plant with } \\
\text { leaves }\end{array}$ & free & $\begin{array}{l}\text { H: lamp heating (ext.) \& } \\
\text { M: with/without } \\
\text { antitranspirant }\end{array}$ & $\begin{array}{l}\text { perpendicular to } \\
\text { plant }\end{array}$ & mixed & $0.4-0.64 \mathrm{~m} / \mathrm{s}$ & $T_{a m b}=25^{\circ} \mathrm{C}$ & - & use of antitranspirants \\
\hline $\begin{array}{l}\text { Domingo et al. } \\
\text { (1996) }\end{array}$ & WT & $\begin{array}{l}2 \text { artif. leaves } \\
\text { (cladode of bush } \\
\& \text { grass) }\end{array}$ & cylindrical $(150 x 2 \mathrm{~mm})$ & $\begin{array}{l}\text { HBM- } \\
\text { TS }\end{array}$ & heat (3 TC) & $\begin{array}{l}\text { stainless steel } \\
\text { (silver painted) }\end{array}$ & fixed & electric. heat. (int.) & perpendicular & mixed & $0.5-5 \mathrm{~m} / \mathrm{s}$ & - & - & $\begin{array}{l}\text { design of artif. leaves for field } \\
\text { experiments }\end{array}$ \\
\hline $\begin{array}{l}\text { Smith et al. } \\
\text { (1997b) }\end{array}$ & WT & $\begin{array}{l}1 \text { artif. leaf } \\
\text { (neem) }\end{array}$ & $\begin{array}{l}\text { actual shape } \\
(61 \times 24 \mathrm{~mm})\end{array}$ & $\begin{array}{l}\text { HBM- } \\
\text { TS }\end{array}$ & heat (1 TC) & brass & fixed & electric. heat. (int.) & $\begin{array}{l}\text { parallel \& } \\
\text { oblique }\end{array}$ & $\begin{array}{l}\text { free, mixed } \\
\& \text { forc. }\end{array}$ & $0-10 \mathrm{~m} / \mathrm{s}$ & - & $\begin{array}{l}g_{b, h} \sim U_{\infty}{ }^{n}(n=0.36-0.86) \\
N u_{D}=0.664 \beta \operatorname{Re}^{1 / 2} \operatorname{Pr}^{1 / 3}(\beta \\
\left.=1.08-1.31, \operatorname{lam}^{2}\right) \\
N u_{D}=0.036 \beta \operatorname{Re}^{0.8} \operatorname{Pr}^{1 / 3}(\beta \\
=1.39-1.92, \text { turb. })\end{array}$ & $\begin{array}{l}\text { testing artif. leaves for field } \\
\text { experiments }\end{array}$ \\
\hline $\begin{array}{l}\text { Daudet et al. } \\
\text { (1998) }\end{array}$ & WT & $\begin{array}{l}2 \text { artif. leaves (1 } \\
\text { vine \& } 1 \\
\text { circular) }\end{array}$ & $\begin{array}{l}\text { actual shape \& circular } \\
\text { (diam. } 130 \mathrm{~mm} \text { ) }\end{array}$ & $\begin{array}{l}\text { HBM- } \\
\text { TS }\end{array}$ & heat $(6 \mathrm{TC})$ & copper & fixed & electric. heat. (int.) & parallel & $\begin{array}{l}\text { free, mixed } \\
\& \text { forc. }\end{array}$ & $0-4 \mathrm{~m} / \mathrm{s}$ & - & $g_{b, h}=0.0106 U_{\infty}^{0.53}$ & $\begin{array}{l}\text { calibration of artif. leaves for } \\
\text { field experiments }\end{array}$ \\
\hline $\begin{array}{l}\text { Grantz and } \\
\text { Vaughn (1999) }\end{array}$ & $\begin{array}{l}\text { lab. } \\
\text { (fan) }\end{array}$ & $\begin{array}{l}2 \text { artif. leaves } \\
\text { (cotton) }\end{array}$ & $\begin{array}{l}\text { actual shapes }(100- \\
150 \mathrm{~mm})\end{array}$ & $\begin{array}{l}\text { HBM- } \\
\text { TS, PM }\end{array}$ & $\begin{array}{l}\begin{array}{l}\text { heat (4-6 TC) \& } \\
\text { mass (grav.) }\end{array} \\
\end{array}$ & $\begin{array}{l}\text { brass (nickel } \\
\text { plated) \& filter }\end{array}$ & fixed & $\begin{array}{l}\text { H: electric. heat. (int.) \& } \\
\text { M: wet filter paper }\end{array}$ & parallel & $\begin{array}{l}\text { mixed \& } \\
\text { forc. }\end{array}$ & $<5 \mathrm{~m} / \mathrm{s}$ & - & $g_{b, h}=2 \beta\left(0.6 \alpha\left(U_{\alpha} /(l v)\right)^{0.5}\right)$ & $\begin{array}{l}\text { design \& calibration of artif. } \\
\text { leaves for field experiments }\end{array}$ \\
\hline
\end{tabular}




\begin{tabular}{|c|c|c|c|c|c|c|c|c|c|c|c|c|c|c|}
\hline & & & & & & paper & & & & & & & & \\
\hline $\begin{array}{l}\text { Martin et al. } \\
\text { (1999) }\end{array}$ & WT & $\begin{array}{l}\text { real branches } \\
\text { (silver fir) }\end{array}$ & actual shapes & WLT & $\begin{array}{l}\text { heat }(4 \mathrm{TC}) \& \text { mass } \\
\text { (grav.) }\end{array}$ & $\begin{array}{l}\text { branch \& } \\
\text { needles } \\
\text { (plaster- } \\
\text { coated) }\end{array}$ & free & wet plaster & perpendicular & $\begin{array}{l}\text { mixed \& } \\
\text { forc. }\end{array}$ & $0.05-5 \mathrm{~m} / \mathrm{s}$ & - & $g_{b, m}=0.0708 U_{\infty}+0.0576$ & $\begin{array}{l}\text { comparison with field } \\
\text { experiments }\end{array}$ \\
\hline $\begin{array}{l}\text { Michaletz and } \\
\text { Johnson (2006) }\end{array}$ & WT & $\begin{array}{l}\text { real branches \& } \\
\text { buds ( } 2 \text { conifer } \\
\text { species) }\end{array}$ & $\begin{array}{l}\text { actual shapes } \\
(\sim 300 \mathrm{~mm})\end{array}$ & CCT & $\begin{array}{l}\text { heat (multiple TC } \\
\text { inside branch) }\end{array}$ & $\begin{array}{l}\text { branches \& } \\
\text { buds }\end{array}$ & free & frozen branches & perpendicular & forc. & $\begin{array}{l}0.16- \\
6.95 \mathrm{~m} / \mathrm{s}\end{array}$ & $T_{a m b}=23^{\circ} \mathrm{C}$ & $\begin{array}{l}N u_{x}=a R^{n}(a=0.017-0.7 \\
n=0.66-0.91)\end{array}$ & $\begin{array}{l}\text { foliage; branches \& buds; } \\
\text { lumped capacitance analysis }\end{array}$ \\
\hline $\begin{array}{l}\text { Roy et al. } \\
\text { (2008) }\end{array}$ & $\begin{array}{l}\text { lab. } \\
\text { (MC) }\end{array}$ & 1 real leaf (bean) & circular (diam. $55 \mathrm{~mm}$ ) & HBM & heat $(4 \mathrm{TC})$ & leaf & fixed & lamp heating (ext.) & parallel & mixed & $\begin{array}{l}0.0138- \\
0.276 \mathrm{~m} / \mathrm{s} \\
\end{array}$ & $\begin{array}{l}T_{a m b} \sim 25- \\
26^{\circ} \mathrm{C} \\
\end{array}$ & - & $\begin{array}{l}\text { CFD validation; dark \& light } \\
\text { periods }\end{array}$ \\
\hline
\end{tabular}


Table 4. Characteristics of numerical studies on convective scalar transfer from leaves.

\begin{tabular}{|c|c|c|c|c|c|c|c|c|c|c|c|c|c|c|}
\hline Author & Setup & Leaf type & Morphology and size & Method & $\begin{array}{l}\text { Simulated } \\
\text { parameter }\end{array}$ & $\begin{array}{l}\text { Leaf } \\
\text { material }\end{array}$ & Leaf status & $\begin{array}{l}\text { Boundary } \\
\text { conditions }\end{array}$ & Flow configuration & Flow regime & Air speed & Temp. & Correlation & Remarks, aims, keywords \\
\hline $\begin{array}{l}\text { Roth-Nebelsick } \\
(2001)\end{array}$ & leaf in air & $\begin{array}{l}4 \text { leaves (artif., } \\
\text { maple \& lilac) }\end{array}$ & $\begin{array}{l}\text { square }(41.6 \mathrm{~mm}, 0.1 \mathrm{~mm} \text { thick }) \& \\
\text { actual shape }\left(1730 \mathrm{~mm}^{2}, 0.1 \mathrm{~mm} \text { thick }\right)\end{array}$ & $\begin{array}{l}\text { 3D FEM - steady } \\
\& \text { trans. }\end{array}$ & air flow \& heat & leaf & fixed & const. flux & parallel \& oblique & $\begin{array}{l}\text { free \& } \\
\text { mixed }\end{array}$ & $0-0.1 \mathrm{~m} / \mathrm{s}$ & $\begin{array}{l}T_{a m b}=25^{\circ} \mathrm{C} \\
\Delta T<14^{\circ} \mathrm{C}\end{array}$ & - & $\begin{array}{l}\text { steady \& trans.; leaf shapes; no } \\
\text { validation; no turbulence }\end{array}$ \\
\hline $\begin{array}{l}\text { Roy et al. } \\
\text { (2008) }\end{array}$ & leaf in MC & 1 leaf (bean) & circular (diam. 55mm) & 3D FVM - steady & $\begin{array}{l}\text { air flow, heat \& } \\
\text { water vapour }\end{array}$ & leaf & fixed & $\begin{array}{l}\text { lamp heating } \\
\text { (ext.) }\end{array}$ & parallel & mixed & $\begin{array}{l}0.0138- \\
0.276 \mathrm{~m} / \mathrm{s}\end{array}$ & $\begin{array}{l}T_{a m b} \sim 25- \\
26^{\circ} \mathrm{C}\end{array}$ & - & $\begin{array}{l}\text { experimental validation; no } \\
\text { turbulence; dark \& light periods }\end{array}$ \\
\hline
\end{tabular}

